\title{
Doing Labor Activism in South China
}

How did labor NGOs come into existence in contemporary China? How do labor activists act - or not act - when the limits of state tolerance are unclear? With a focus on labor NGOs in South China and Western funding agencies, this book sets out to address these questions by investigating the dynamics of state control in post-socialist China since the 1970s, in which rapid economic and social transformations have cultivated an environment of uncertainty.

Taking uncertainty as an analytical space, productive of emergent practices and discourses, this book draws on original fieldwork and interviews to study the lived experiences of different actors throughout the labor NGO community, the foreign donors trying to bring about change, and the networks of social relationships being strategically reconfigured.

Doing Labor Activism in South China offers an ethnography of the Chinese state that reveals an intimate and complicit modality of self-governing, demonstrating how neoliberal ideas are at once represented by international development and deflected in grassroots development. It will be useful to students and scholars of Social Anthropology and Urban Ethnography, as well as Political Science and Chinese Studies more generally.

Darcy Pan is a social anthropologist whose research focuses on the state, labor, infrastructure, area studies specific to China, technology and urban development. She is a postdoctoral research fellow in the department of Social Anthropology at Stockholm University, Sweden. Her most recent work has been published in the Handbook of Dissident and Protest in China (2019). 


\section{Routledge Contemporary China Series}

208 Ecology and Chinese-Language Ecocinema

Reimagining a Field

Edited by Sheldon H. Lu and Haomin Gong

209 Civilian Participants in the Cultural Revolution

Being Vulnerable and Being Responsible

Francis K.T. Mok

210 Hong Kong's New Identity Politics

Longing for the Local in the Shadow of China

Iam-chong Ip

211 Youth Economy, Crisis, and Reinvention in Twenty-First-Century China Morning Sun in the Tiny Times

Hui Faye Xiao

212 The Chinese Economy and its Challenges

Transformation of a Rising Economic Power

Charles C.L. Kwong

213 Keywords in Queer Sinophone Studies

Edited by Howard Chiang and Alvin K. Wong

214 Macau 20 Years after the Handover

Changes and Challenges under "One Country, Two Systems"

Edited by Meng U Ieong

\section{Doing Labor Activism in South China}

The Complicity of Uncertainty

Darcy Pan

For more information about this series, please visit: https://www.routledge. com/Routledge-Contemporary-China-Series/book-series/SE0768 


\title{
Doing Labor Activism in South China
}

The Complicity of Uncertainty

\author{
Darcy Pan
}

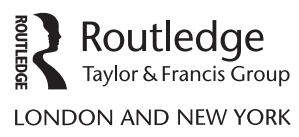


First published 2020

by Routledge

2 Park Square, Milton Park, Abingdon, Oxon OX14 4RN

and by Routledge

52 Vanderbilt Avenue, New York, NY 10017

Routledge is an imprint of the Taylor \& Francis Group, an informa business

(C) 2020 Darcy Pan

The right of Darcy Pan to be identified as author of this work has been asserted by her in accordance with sections 77 and 78 of the Copyright, Designs and Patents Act 1988.

All rights reserved. No part of this book may be reprinted or reproduced or utilised in any form or by any electronic, mechanical, or other means, now known or hereafter invented, including photocopying and recording, or in any information storage or retrieval system, without permission in writing from the publishers.

Trademark notice: Product or corporate names may be trademarks or registered trademarks, and are used only for identification and explanation without intent to infringe.

British Library Cataloguing-in-Publication Data

A catalogue record for this book is available from the British Library

Library of Congress Cataloging-in-Publication Data

Names: Pan, Darcy, author.

Title: Doing labor activism in South China : the complicity of uncertainty / Darcy Pan.

Description: Abingdon, Oxon ; New York, NY : Routledge, 2020. | Series: Routledge contemporary China series |

Includes bibliographical references and index.

Identifiers: LCCN 2020007721 (print) | LCCN 2020007722 (ebook) |

ISBN 9780367406752 (hardback) | ISBN 9780367810092 (ebook)

Subjects: LCSH: Labor movement-China. | Labor unions-China. |

Non-governmental organizations-China. | China-Economic

policy-1949- | China-Economic conditions - 1949-

Classification: LCC HD8734 .P35 2020 (print) |

LCC HD8734 (ebook) | DDC 331.8809512 - dc23

LC record available at https://lccn.loc.gov/2020007721

LC ebook record available at https://lccn.loc.gov/2020007722

ISBN: 978-0-367-40675-2 (hbk)

ISBN: 978-0-367-81009-2 (ebk)

Typeset in Times New Roman

by codeMantra 


\section{Contents}

Acknowledgments vii

A note on names, translations, and currency issues ix

Introduction 1

1 Locating uncertainty 23

2 Pragmatic state, precarious labor 47

3 Uncertainty at work $\quad 78$

4 The politics of mingan 105

5 Intimating secrecy 135

6 Collective action 165

Conclusion: laboring through uncertainty $\quad 188$

$\begin{array}{ll}\text { Index } & 199\end{array}$ 

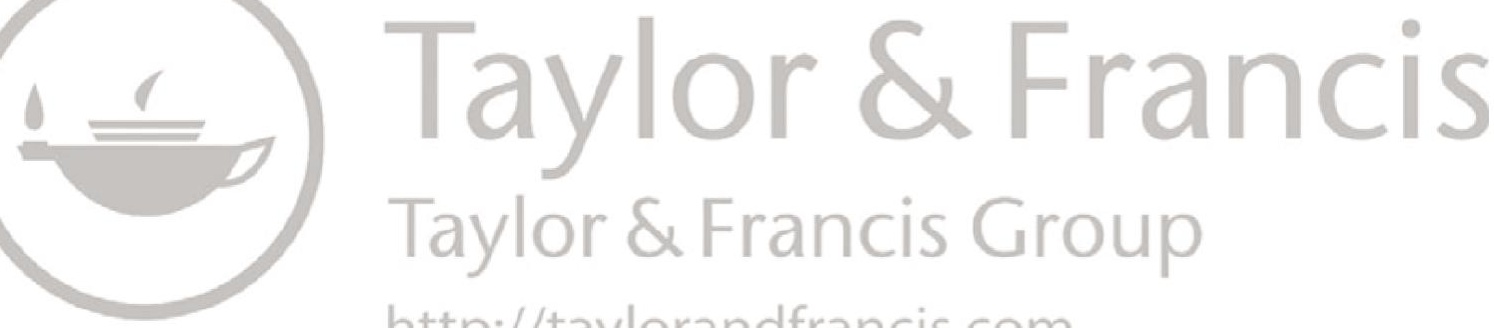

http://taylorandfrancis.com 


\section{Acknowledgments}

This book is based on my $\mathrm{PhD}$ dissertation, which was completed in 2016 in the Department of Social Anthropology at Stockholm University. The research on which my $\mathrm{PhD}$ study is based was generously funded by grants from Forum for Asian Studies, Helge Ax:son Johnson Foundation, the Swedish Society for Anthropology and Geography, and the Department of Social Anthropology, Stockholm University. They funded the different stages of my fieldwork in 2012-2013. Scholarship from the Sweden-America Foundation gave me the opportunity to spend one year in the Department of Anthropology at Yale University from 2014 to 2015 to focus on writing my dissertation.

In China and Hong Kong, I am truly grateful to all the people whom I met and spent time with, many of whom have become good friends. Nearly all of them have been given pseudonyms in this study. I hope that the perspective I offer will in some way repay their interest and kindness. I thank Anthony Spires at the University of Melbourne for inspiring discussions at the early stage of my fieldwork.

In Taiwan, I am grateful for Chih-jou Jay Chen at Academia Sinica and Hsing-chung Wang at Soochow University for helping me make contacts in Guangzhou at the early stage of my fieldwork.

In the Department of Social Anthropology at Stockholm University, Johan Lindquist has been my mentor since I began my graduate education. $\mathrm{He}$ has read and commented on several versions of this study and continuously shown confidence in me and this project, and pushed me to broaden and deepen my understanding of and engagement with contemporary issues in anthropology and social theory. I cannot express enough my gratitude to him for being a guide and an interlocutor for so many years. As my second advisor, Anette Nyqvist has offered her unwavering support and has had faith in me and has given me invaluable comments as I wrote and revised the study. Along with these people, I have been sustained by conversations with Ulf Hannerz, Helena Wulff, Shahram Khosravi, Mark Graham, Renita Thedvall, Paula Uimonen, and Dolly Kikon. I am also indebted to the graduate students and the administrative staff at the department. I thank Hege Høyer Leivestad, Peter Skoglund, and Lina Lorentz for guiding and helping me with the practicalities. 
I was affiliated with the Asia Research Institute at National University of Singapore during the summer of 2010. I thank Brenda Yeoh for the invitation which allowed me to conduct some preliminary fieldwork in the region. I am also grateful for Melody Lu, Lai An-Eng, Lan Anh, Cheryll Alipio, Shu-yi Pearl Wang, and Mika Toyota for inspiring conversations and support. I would also like to extend my gratitude to all the administrative staff at the Asia Research Institute for making my visit so comfortable and memorable. During the winter of 2010, I had the opportunity to do some coursework at the Institute of Social and Cultural Anthropology at University of Oxford. I am grateful for Xiang Biao's invitation and letting me be part of the stimulating research environment.

I spent the academic year 2014-2015 in the Department of Anthropology at Yale University. I am grateful for the Sweden-America Foundation for funding my stay. I would like to thank Erik Harms for inviting me and allowing me to be part of the stimulating and vibrant academic environment. I would also like to thank the administrative staff Marlene Cullen for helping me settle and get situated as smoothly as possible in the beginning of my arrival. I am hugely indebted to Paul Kockelman who has generously read the early version of several chapters and offered comments and ideas that have been crucial in shaping the direction of the study. I am also grateful for Helen Siu who has shared her expertise in Chinese studies and offered practical guidance of teasing out the conceptual issues in my own work. I would also like to thank Kalyanakrishnan Sivaramakrishnan who kindly shared with me his expertise in development studies and offered some constructive suggestions in the early stage of my writing.

I am also indebted to Graham Jones in the Department of Anthropology at Massachusetts Institute of Technology for helping me think through some of the issues and the structure of the study. I would also like to convey my heartfelt gratitude and sincere appreciation to Michael Herzfeld at Harvard University who was the discussant of the final discussion of my doctoral thesis. He has given me invaluable and inspiring comments that have made the last stage of writing up a truly rewarding experience. I cannot thank him enough.

This book would not have seen the light of the day without the support of my friends who have believed in me and supported me through these years. I thank Jennifer Lindsay for excellent copyediting of my dissertation. I would also like to thank Alan Lindsay for being a great teacher and friend in supporting my writing for so many years.

Finally, I want to express my deepest gratitude to my family, including my cat August, who have been supportive in many different ways, and through all different phases of my life. 


\title{
A note on names, translations, and currency issues
}

\begin{abstract}
All translations of textual and spoken materials from Chinese to English that appear in this book were done by the author. The Pinyin System for Romanizing Chinese characters is used throughout the text. In an effort to ensure the safety and security of my informants living and working in mainland China and Hong Kong, I have changed the names of the people and organizations and have left references that could identify them out of the bibliography. Therefore, all the Chinese names of individuals, organizations, and factories are pseudonyms, if not otherwise specified. The personal names are written as they would be in Chinese; that is, the family name is followed by the first name. The names of the provinces and cities are real names, while the names of districts and villages are pseudonyms in order to protect the identity of the individuals and organizations where I conducted fieldwork. In this book, I have chosen and translated certain terms and phrases from Chinese to English because they are specific Chinese terms and have specific meanings in the contexts where they were uttered and used. I have included the Chinese characters together with the English translations in order to ensure that their meanings are not compromised too much by translation.

The official currency of the PRC is the renminbi and is abbreviated RMB. Throughout this study I will use primarily the renminbi and the U.S. dollar, and, unless otherwise noted, the rate was $6.66 \mathrm{RMB}$ per dollar during the time of my fieldwork.
\end{abstract}



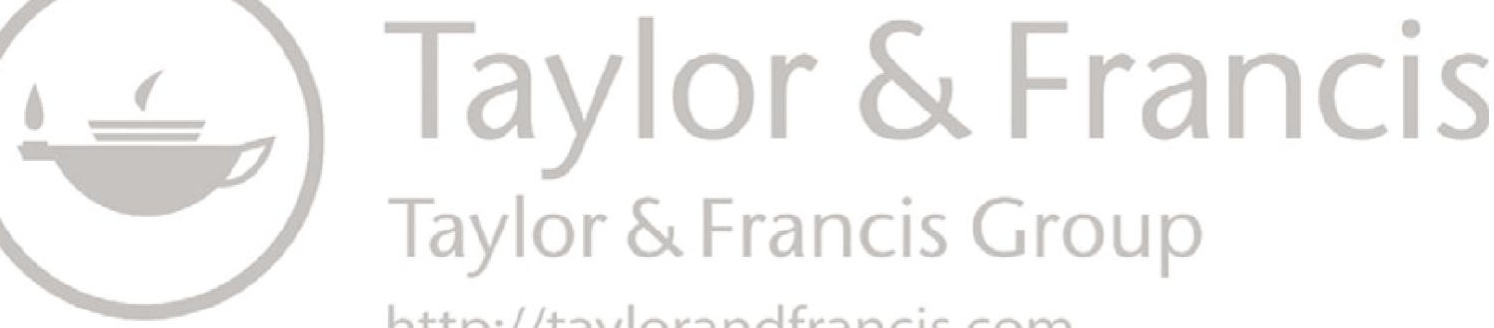

http://taylorandfrancis.com 


\section{Introduction}

"Any new gossip?" Mandy asked with a mischievous smile. It was a February afternoon in 2013 in the office of the Chinese Workers' Front (CWF), a Hong Kong-based nongovernmental labor organization (hereafter referred to as labor NGO). This was Mandy's way of checking how my research had been going and if I was willing to share any information I had obtained from the labor NGOs I had been working with, some of which were CWF's partners. Mandy was the coordinator for CWF's projects in mainland China ${ }^{1}$ and the main contact person for their partner NGOs there. She tried to maintain contact with each partner on a daily basis, mainly by phone and email, and also conducted on-site visits to partners at least once a month. Additional visits would be scheduled if the donors were in town and wanted to visit the organizations they support. I had been going to CWF for the past few months to either meet with staff or participate in workshops, and on this day I was meeting Mandy to talk about CWF's projects in China.

Mandy was always keen to know more about these NGOs so that she could, as she put it, "manage the projects better." In response, I told Mandy one new piece of information about myself that I had recently heard from a labor NGO staff member. The director of the labor NGO where I was conducting fieldwork at the time had given my resumé to the local police. Mandy let out a light laugh and said calmly,

I am not surprised at all. I know he has been giving information [to the state security agents]. He even gives away information about the workers. Whose side is he on? I understand that you need to give information but you need to have a bottom line (dixian). Don't you think? You can't just give whatever they ask for.

Mandy continued,

You know CWF is a bit sensitive (mingan). But we can still carry out our work in China. It requires some skill (jiqiao). Some things need to be kept secret and some things need to be compromised. We can compromise so that's not a problem. But it is hard to trust [people] because 


\section{Introduction}

you don't always know what's going on [between the NGOs and the government]. It's very ambiguous (hen aimei).

It seemed I had touched on a topic that Mandy felt strongly about and she felt compelled to express her opinion. Sounding both frustrated and demoralized, Mandy noted that the lack of transparency of CWF's partners was a serious issue. She said,

Many NGOs use government surveillance as a shield to justify the fact that they can't share all the information with their partners. This makes it very convenient [for these NGOs] to keep some information to themselves. It's a really big issue for us. I feel that in the mainland (neidi), the more slippery [labor NGOs] get around better (yu huatou hun de yu hao) because they know how to handle and mingle (zhouxuan) with different people. I thought about quitting my job because I didn't want to deal with people like that every day.

Suddenly one of Mandy's colleagues knocked on the door and popped in to say that there was a phone call for her. Left alone in the conference room, I was somewhat struck by how Mandy's words were palpably tinged with jaded professionalism, mission fatigue, and even some cynicism, revealing a gloomy outlook for the development of labor NGOs in China.

This book examines the workings of Chinese state power by exploring how development projects supporting labor activism are implemented in a restrictive political climate in which the limits of state tolerance are uncertain. Focusing on labor NGOs in both mainland China and Hong Kong, and their foreign donors, this study aims to illustrate how the Chinese state is embedded and enacted at the margins of the nation-state in which practices, discourses, and relationships are created, reinforced, and maintained (Das \& Poole 2004: 3), and how the effect of state power is not all-encompassing but uneven, which, in turn, creates an ambiguous boundary between state and society and thus a contingent space of activism. More specifically, I am concerned with two sets of empirical questions: The first deals with the social, political, and economic conditions under which labor activists and NGOs have emerged in South China. How did labor NGOs come into existence in an authoritarian regime? What do the labor NGOs do? What role does the international community play in the development and survival of the labor NGOs in China? How do international funds trickle down to these labor NGOs? The second focuses on the political and economic processes that have made political space available to labor NGOs in contemporary China. What are these processes and what effects do they have? How do the labor NGOs engage with these processes while trying to build the labor movement and induce social change? How do the labor NGOs carry out their work when the boundaries of state tolerance of labor activism are often uncertain and ambiguous? Essentially, these two sets of questions address the 
relationship between trust and power: How do labor activists establish trust relationships and negotiate power among them, and contend with state control under the uncertain circumstances fostered by the Chinese state?

With the aim of exploring the dynamics of state control and the specific workings of state power in contemporary China, I treat uncertainty as an analytical and ethnographic space that is (re)productive of emergent practices, discourses, and modes of existence that strategically configure and reconfigure social relationships among different actors while masking and unmasking the state. It is in such a space that I situate and study the lived experiences of everyday life and relationships among a group of labor NGOs in Guangdong Province and Hong Kong, and Western funding agencies that try to bring about change in post-socialist China where rapid economic and social transformations since the 1970s have unleashed diverse social forces and cultivated an environment of uncertainty in social, political, and moral terms (Liu 2000; Ku 2003; Oxfeld 2010; Heilmann \& Perry 2011). More specifically, I investigate how a social realm — a contested boundary between state and society - located in the margins of the state has emerged in the midst of uncertainty. By "social" I mean those "not-to-becompartmentalized dimensions of the human experience" (Shue 1988: 27). It is in this social realm that I examine how variously positioned subjects mobilize around the idea of the state, which, in turn, leads to articulations and practices of dealing with the state. The state becomes an enabler whereby certain kinds of knowledge, practices, relationships, and networks are made possible and necessary. As such, this social realm is also a space of intimacy (cf. Herzfeld 2016) where different ways of engaging in complicity between the state and social actors can be explored. I thus examine the ways in which uncertainty is (re)productive of knowledge and practices whereby labor activists not only effectively self-censor but also skillfully map the gray zone between relatively safe and unacceptably risky choices.

Foregrounding the uncertainty about the boundaries of permissible political action allows me to shift my analysis of the agency of the subaltern groups from critical moments of resistance to the ways in which "the conceptual boundaries of the state are extended and remade in securing survival or seeking justice in the everyday" (Das \& Poole 2004: 20). I move beyond the common story of state control through coercion and regulation, and look into the ripple effect of how uncertainty affects the agency of those in the margins. How does one gauge the distance from the state when there are limits of knowing and acting? What are the ways of gathering knowledge so as to come to a degree of certainty in the midst of uncertainty? How does uncertainty affect and shape subjectivity? How does one conduct ethnographic fieldwork under uncertain conditions and write an ethnography about these limits of knowing and acting which in turn become the constraints of the ethnographer's knowing and writing?

This study treats the state as an idea that is constantly being imagined, evoked, articulated, embodied, and negotiated by these NGOs and funding 


\section{Introduction}

agencies. As such, the state as an idea has tangible effects on the actors, the institutions, and the relationships between them (Abrams 1988 [1977]; Mitchell 1991, 1999; Taussig 1992, 1997; Sharma \& Gupta 2006). Labor NGOs are a critical site of investigation to illuminate a specific form of organizational arrangement, born of interactions between a variety of domestic and foreign actors as well as with the state (Trouillot 2003). With a focus on the ways in which the partnerships among these organizations are formed and Western funds trickle down to the labor NGOs in mainland China, this study illustrates how the state is constitutive of and constituted in the network of relationships among these labor NGOs and foreign funding foundations. These relationships become the lived experiences of the ongoing processes of state formation or the state as a "structural effect" (Mitchell 1991), and comprehending them is crucial to a more nuanced understanding of the changing state-society relationship in contemporary China. More importantly, by focusing on how the state as an idea is embedded and enacted in networks of relationships among different actors in the labor community, this study offers an ethnography of the Chinese state which illustrates a modality of self-governing in which neoliberal ideas, represented by international development, are reconfigured and deflected in grassroots development.

\section{Background}

After the death of Mao Zedong in 1976, Deng Xiaoping launched a set of radical and comprehensive economic programs to reinvigorate the country's economy. Deng's programs were characterized by a decentralization of economic authority and limited introduction of market mechanisms. During his "Southern Inspection" (nanxun) tour in the special economic zones in 1992, Deng reiterated the importance of boosting the country's economic development and stated that "development is the absolute principle" (fazhan cai shi ying daoli). Deng's selective and pragmatic approach has paid off: China has enjoyed remarkable economic growth that has astonished the world, although this growth is uneven and more beneficial to cities and coastal areas than to rural regions. As economic reforms intensified, the 1990s saw a widespread privatization and bankruptcy of state-owned enterprises, pension and welfare reforms, and a rush of global capital, as well as deepened economic polarization and inequalities.

Since the mid-1990s, labor unrest has been on the rise and described as a source of political and social instability (Lee 2007: 228). Precarious working conditions such as long hours, wage arrears, lax enforcement of health and safety standards, lack of labor contracts, limited access to medical insurance and retirement, and poor housing have led to increasing labor protests and strikes across China. This has been particularly notable in Guangdong, home to a large population of peasants-turned-workers who leave their rural homes and flock to the coast of South China, where labor-intensive, export-oriented, and light industry has concentrated and labor exploitation 
is prevalent (Chan 2001; SACOM 2005). These migrants are often referred to as mingong, peasant workers or liudong renkou, meaning floating population, which consists of people who "float and move, implying that they are not, and will not become, a permanently settled group" (Solinger 1999: 15). Because peasant-turned-workers move to seek employment, they are also commonly referred to as migrant workers, which is the term used in this study.

In the wake of economic reforms, China has been undergoing significant political, economic, and social transformations. China has endured the Tiananmen Uprising, outlasted both Eastern European and Soviet variants of communism, and weathered ethnic riots in 2008 and 2009 (Heilmann \& Perry 2011). Regardless of numerous predictions of its impending demise and the widely shared anticipation of a commensurate political liberalization (Chang 2001; Gilley 2004; Pei 2006; Shirk 2007), China's Communist Party continues to be in power in the wake of astounding economic progress. What intrigues as well as confounds many China observers is not only the continued absence of liberal democratic institutions in the country but also the fact that the Chinese Communist regime has become increasingly adept at managing challenges posed by leadership succession, popular unrest, administrative reorganization, legal institutionalization, and the integration with the global economy. As political scientist Andrew Nathan acknowledges, "One of the puzzles of the post-Tiananmen period has been the regime's apparent ability to rehabilitate its legitimacy" (Nathan 2003: 13).

Without doubt, the discrepancy between economic growth and political liberalization in China comes at a great cost. Ordinary Chinese citizens are still deprived of civil liberties. The absence of political restraints has contributed to cadre corruption, labor exploitation, poor protection of consumers, environmental degradation, and increasing social inequality. In spite of these numerous problems, the Chinese Communist regime continues to govern, which raises the question of legitimacy, a subject to be addressed in Chapter 2. When discussing Chinese politics, one is readily reminded of stories of heavy-handed repression and violence. The "interplay of repression and resistance" (Heilmann \& Perry 2011: 4) animates and dominates the popular imagination of the political situation in China. But these stories do not reveal a more nuanced face of the Chinese Communist regime. Coercion is not a staple of daily political life. As Stern and Hassid point out, the number of people that are in effect severely punished or imprisoned makes up fewer than $1 \%$ of the activists in China. So, the question is, What keeps the other $99 \%$ in line? (Stern \& Hassid 2012). How does the Chinese state secure compliance from the governed? I suggest that foregrounding the uncertainty of the political life in post-socialist China can shed light on these questions.

\section{Thinking through uncertainty}

In this book, I use uncertainty to include situations of ambiguity, indeterminacy, and contradictions as well as tensions and contingencies that arise 


\section{Introduction}

from such situations. Uncertainty is inextricably entangled with human existence and figures as a powerful motivation in our striving for knowledge. Uncertainty prompts us to try to predict the future so as to hopefully generate more certainty when confronted with the unknown (Nowotny 2015). Anthropological theory has long privileged the discovery of order and regularities of everyday life (Radcliffe-Brown 1922; Malinowski 1944; LéviStrauss 1963 [1958]; James 1995; Geertz 2000 [1973]; Benedict 2005 [1934]). Since the 1980s, there has been a gradual theoretical shift to address the shortcomings of structuralist approaches in linguistics and social sciences (Derrida 1976, 1978, 1994, 1997; Foucault 1984, 1992 [1978], 2002 [1969], 2002 [1970]; Ortner 1984; Sahlins 1985; Moore 1987; Deleuze 1994; Das 1995; Niehaus 2013). This broad theoretical shift reflects a loss of confidence in the explanatory sufficiency of the capacity and coherence of structures, that is, encompassing systems, durable social forms, regular occurrences, and everyday practices. It has become apparent that while a focus on regularities and consistency can shed light on some areas of social life, it also obscures and ignores other irregular, transitory, uncertain, anomalous, or ambiguous forms, practices, and events. More importantly, this theoretical imbalance prevents us from contemplating the "substantial areas of normative indeterminacy" (Moore 1987: 729) and developing social theory of irregularity, unpredictability, precariousness, inconstancy, and fickleness - in other words, a social theory of uncertainty.

Some scholars have addressed this conceptual imbalance and underscored the productivity of uncertainty and indeterminacy. Bruno Latour (2005) accentuates and uses uncertainties to name strategies that assemble and disassemble research sites and forge research practices because he wants to curb social scientists' inclinations to cling to stable stories. Questioning the common view that writing fixes and secures relations among people, things, and places, Matthew Hull's work on the materiality of bureaucracy in urban Pakistan illustrates how indeterminacy and equivocation can be generated from the mediation of documents (2012; cf. Riles 2006). In line with the recent turn to the ambiguous, indeterminate, and unpredictable, I foreground uncertainty in my study so as to further explore ongoing discourses, events, practices, and processes of negotiating with, dismantling, or creating rules, orders, temporalities, and spatialities.

Uncertainty is often associated with and translated into the language of risk and danger in anthropological thought and practice (Cancian 1980; Cashdan 1990; Adams 1997; Rosa 1998; Boholm 2003). Earlier approaches to risk, notably those framed in terms of culture (Douglas \& Wildavsky 1982) and modernization (Beck 1992; Giddens 2000), have positivistic inclinations, as risk, danger, and uncertainty are treated as things that can be observed, perceived, calculated, and dealt with. Thus, they are often lumped together as observable objects. In contrast, Niklas Luhmann (1993) considers risk not as an object in a first-order observation but as a concept in a second-order observation. By differentiating between two levels 
of observation in a system, Luhmann distinguishes risk from danger, as the former is contingent on the system whereas the latter is caused by forces outside of the system (1993: 21-28). Crucial to Luhmann's treatment of risk and danger is his focus not on the quality or quantity of dangers in the world but on "the mode of observing risk as conceptually inherent to modern systems and how each decision or abstention from decision concerning the future determines risk" (Samimian-Darash \& Rabinow 2015: 3). As it will become clear later in the book, this distinction made by Luhmann bears great relevance to my discussion of how Chinese labor NGOs deal with state surveillance while implementing development projects of labor activism funded by Western organizations. Under the restrictive political conditions, the ways in which Chinese labor activists conduct themselves closely hinge on how they view the Chinese state, which, in turn, sets the parameters of their activism work so that they can gauge and diminish risk, and try to work in a way that will not be deemed as an affront to the state.

Predicated on how the Chinese state and the associated potential risk are perceived, the parameters of these NGOs' work give rise to knowledge, practices, tactics, and strategies created with the hope to mitigate risk and estimate the appropriate distance from the Chinese state. This is similar to what Limor Samimian-Darash and Paul Rabinow's emphasis of how certain knowledge and practices are circulated and made available to deal with risk, danger, and uncertainty, which should be treated as distinct concepts both analytically and anthropologically (Samimian-Darash \& Rabinow 2015: 1). This is because "the world is increasingly being populated by forms, practices, and events of uncertainty that cannot be reduced to risk" (ibid.). Considering uncertainty as a distinct concept, according to SamimianDarash and Rabinow, directs the analytical and anthropological attention to "emergent problem spaces" (ibid.) that consider the understanding of, representation of, and response to the problems at hand which then allow us to examine what and how forms of governing and modes of subjectivity have developed.

Drawing attention to "emergent problem spaces" makes an analytical shift from the control of risk to the management of uncertainty. With the control of risk, the emphasis is placed on technologies designed to identify, prevent, and control risk - in other words, making risk governable, and, as such, a mode of governance (Rose 1999 [1989], 2008 [1999]). In contrast, the management of uncertainty relies on technologies that focus on precaution and preparedness. Technologies of uncertainty rely on past information to make predictions about future events and propose which preparedness practices in response. Technologies of uncertainty thus lay emphasis on the ways in which observations about uncertainty are made and come to circulate in the contemporary world and thus constitute a new problematic field for which certain policies and practices emerge as solutions (Samimian-Darash \& Rabinow 2015: 3). As such, uncertainty can be viewed as a productive and constitutive concept that can be mobilized to generate and facilitate 


\section{Introduction}

discourses, forms, and practices. Following Luhmann and Limor SamimianDarash and Paul Rabinow, this book analyzes the relationship between Chinese labor NGOs and the state through the prism of uncertainty so as to open up an analytical space in which how Chinese labor NGOs manage and negotiate the uncertain limits of state-sanctioned activism can be examined. By doing so, I hope to illustrate and understand the often-elusive state-society dynamics that are deeply enmeshed within historical, political, and social fabrics.

That uncertainty should be treated as a productive concept instead of a problem, an irregularity, or a misfortune to be faced, avoided, or solved is also highlighted in recent research on the subject of governance in China. Researchers of Chinese politics have been turning to such words as uncertainty (Link 2002; Hassid 2008; Yang 2009: 188; Dillon 2011; Heilmann \& Perry 2011; Stern \& Hassid 2012), ambiguity (O’Brien \& Li 2006: 63; McNally 2011), and ambivalence (deLisle 2004; Shue 2004: 41; O'Brien \& Li 2006: 31; Levy 2007: 47; Yang 2008: 131; Lee 2010: 51; Xu \& Pu 2010: 164) to delineate the "dual, almost schizophrenic nature" (Litzinger 2007: 298; cf. Taussig 1992) of the Chinese state. Many of these studies focus their attention on how the uncertainty and ambiguity of the Chinese government's policy and guidelines create a prevalent sense of indeterminacy, arbitrariness, and insecurity that work as a "control mechanism" or "regime of uncertainty" to keep the majority of the population in line (Hassid 2008: 415; see also Stern \& Hassid 2012; Pan 2019). ${ }^{2}$

This body of literature not only shows that uncertainty is a common characteristic of Chinese politics but also serves as an important point of entry to understand the specific workings of state power. It shows that uncertainty becomes a technology of power that is productive and generative of a certain kind of order when used skillfully. Inherent in this use of the notion of uncertainty is that information or signals that are being transmitted and conveyed by the Chinese state are unclear and incomplete and thus subject to interpretation (Perry 2002; Stern \& O'Brien 2012) whereby modes of observation of uncertainty can be extrapolated. Chinese activists have to grapple with "correctly" reading mixed signals, which provide clues to assess opportunities and threats. Addressing the mixed signals of the Chinese state, Stern and Hassid argue, allows us to move beyond "some well-patrolled forbidden zones" and see how "the state speaks with many, contradictory voices” (Stern \& O’Brien 2012: 177). It also allows us to unsettle the visual metaphor of the state as an observer watching from a singular perspective (Scott 1998) that often leads to the assumption that there is a unity of state representations and falls short of illustrating "how such unity is achieved (or not) through coordination in practice" (Hull 2012: 166).

Taking the notion of uncertainty as the theoretical point of departure for this book, I study political life in contemporary China by investigating how labor NGOs, individual activists, and donors manifest a certain mode of being, acting, and knowing in contemporary China. In this book, the 
notion of uncertainty serves both analytical and methodological purposes. I will develop the methodological parameters in Chapter 1. Here, following Luhmann (1993), I treat uncertainty as an analytical concept to understand the political, social, and economic conditions under which these labor NGOs operate. This opens up an analytical and ethnographic space where the dynamics between state control, practices of self-censorship, and performances of labor activism can be conceptualized as a relationship fraught with and generative of negotiations with, mediations of, and enactments of discourses, relationships, and practices. With this analytical move, I explore what forms and practices of gauging the limits of state tolerance have emerged in shaping and conditioning the relationships between the labor NGO sector (labor NGOs, donors, labor scholars, and media) and the state. These forms and practices are illustrated by informal ways of communication such as gossip, rumor, and storytelling, and practices of activism and secrecy, which are often characterized by a tactful balancing and situational act between the state, labor NGOs, and donors. It is true that informality, gossip, rumor, and secrecy are not unique to China. These informal ways of communication and practices exist in both liberal democracies and authoritarian regimes. But as my study shows, these informal practices become imperative to the existence and survival of Chinese labor NGOs when they operate in a political landscape where uncertainty is a technology of state power. The extent to which the Chinese state deliberately and quite successfully deploys and allows uncertainty, ambiguity, and arbitrariness to seep into its making and implementation of policies and regulations is unparalleled among other authoritarian countries. This makes uncertainty an important point of entry into an understanding of contemporary Chinese politics. While uncertainty serves as the analytical lens to situate and anchor this study, the informal communication practices of gossip, rumor, and secrecy are the heuristic and ethnographic moments and spaces where uncertainty is experienced, conveyed, and discussed. In the chapters that follow, I will illustrate ethnographically how such forms and practices, which are enactments of how uncertainty is observed and managed, are played out and can be understood as epistemological mediations of trust in situations of uncertainty when the permitted boundaries of activism are unclear.

\section{Notions of the state}

At the center of the domain of uncertainty is the idea of the Chinese state, which often evokes an opaque, skeletal, ghostly, and monolithic image (Nettle 1968: 559; Shue 1988: 17). The ambiguous perception of the Chinese state opens up an ethnographic space in which we can conceptualize how different relationships and subjectivities are cultivated, formed, mobilized, and managed against the unclear idea about the state. Anthropological interest in the state has increased considerably since the beginning of the 1990s as shown by a number of recent publications (Mitchell 1991; Taussig 1992, 1997; 
Hansen \& Stepputat 2001; Ferguson \& Gupta 2002; Trouillot 2003; Das \& Poole 2004; Geertz 2004; Elyachar 2005; Yang 2005; Sharma \& Gupta 2006; Gupta 2012; Hull 2012). These publications can be viewed in light of the "cultural turn" in the study of the state (Steinmetz 1999), which attempted to address the issue of how to determine appropriate approaches and levels to study the state. In the 1940s, Radcliffe-Brown had already argued against taking the state as an empirical object of study and urged researchers to direct attention to more concrete forms of political organizations, relations, and individuals (Radcliffe-Brown 1987 [1940]: xxiii).

In contrast to Radcliffe-Brown's call to abandon the state as the object of study, Philip Abrams directed the analytical attention to the idea of the state and described the state-idea as an ideological project that legitimates subjection, a claim to domination, and a mask that hides the institutionalization of political power in the state system (Abrams 1988 [1977]; see also Sharma \& Gupta 2006: 46). Abrams's analysis of the state-idea as an ideological project has been influential and led many anthropologists to treat the state as more than just a functional bureaucratic apparatus - a productive site where the state itself is culturally and symbolically constructed and represented. Abrams's conceptualization paints an utterly disturbing picture of the state and reality that prompts Michael Taussig to call it "a thoroughly nervous Nervous System" (Taussig 1992: 113). In line with Abrams's emphasis on the processes whereby the power of the state is exercised, Timothy Mitchell raises a slightly different question of the significance and effects of sustaining the uncertain distinction between the state and society (1991: 89). To mark the boundary between the state and society is an exercise of power that has consequences.

The line between state and society is not the perimeter of an intrinsic entity, which can be thought of as a free-standing object or actor. It is a line drawn internally, within the network of institutional mechanisms through which a certain social and political order is maintained.

(Mitchell 1991: 90, emphasis in original)

The ways in which the state-society distinction, which is uncertain and always contested, are produced and maintained become a mechanism that generates resources of power (ibid.).

A good number of anthropological studies have illustrated and discussed the ways and processes in which such constructions and representations take place (Bayart 1993 [1989]; Joseph \& Nugent 1994; Cohn 1996; Bernal 1997; Coronil 1997; Nugent 1997; Taussig 1997; Comaroff 1998; Scott 1998; Ferguson \& Gupta 2002; Trouillot 2003). Several analytical concepts have been developed to understand these processes such as "the spatialization of states" (Ferguson \& Gupta 2002) and "state effects" (Trouillot 2003). These studies have all illustrated analytical as well as empirical endeavors to move beyond the reification of the state. While doing so, however, they have also 
fallen short of demonstrating the actual workings of the state, more specifically, the particular workings of state power.

In the modern Chinese state, the issue of state power and governance has been discussed in terms of "state involution" (Duara 1987; Siu 1989a, 1989b; Murphy 2007). Although these studies have dealt with different periods of state-making in modern Chinese history, they have all shared a basic line of thinking that, regardless of an appearance of the construction of formal rationality, the formation of a modern state from the republican era onward failed to result in an efficient and transparent state bureaucracy. It is a language of order that is inherited largely from the modern European state (Das \& Poole 2004: 5). Following Duara (1987), many of these studies borrow the concept of "involution" from Geertz's study of Javanese wet rice agriculture (1969 [1963]). According to Geertz, involution is a process through which a social or cultural pattern persists and fails to transform itself into a new pattern even after it has reached a definitive form. Implicit in the notion of "state involution" is a Eurocentric presumption that views the state as well as society to be where they should not be or have failed to be where they should be. It indicates a linear way of thinking about development and implies an attribution of backwardness. As such, the notion of "state involution" also reinforces the treatment of the state and society as separate entities. Not only does the notion of "state involution" run the risk of reifying the state-society relationship, but it also postulates the statesociety relationship in an overly simplistic dichotomy between formal and informal structures (Duara 1987: 132-133; Siu 1989a, 1989b; Lu 2000; Murphy 2007). Hence, it fails to consider the interactional dynamics and processes that are jointly defining contemporary Chinese society.

In order to move away from the reification of state-society relationship and to capture the dynamics of such a relationship, I turn to the idea of uncertainty. This book deals with the subject of uncertainty in Chinese politics and discusses how it creates and shapes a complicit relationship between the Chinese state and labor NGOs. As discussed in the previous section, uncertainty is conceptualized as a technology of power that is generative and constitutive in the sense that it gives rise to discourses, informal communication practices, tactics, and strategies that help the NGOs to deal with the Chinese state. Here, the work of Abrams and Mitchell is relevant to my analysis of the state-society relationship in South China. Abrams's theory of the state-idea as an ideological project opens up an analytical space where one can discuss the discursive work of how the state is conceived, experienced, talked about, and acted on. By describing the state as a "spurious object of sociological concern" (Abrams 1988 [1977]: 63), Abrams urges that our understanding of the state cannot be further advanced unless it is acknowledged that the state is illusory referencing Marx and Engels- "the state constitutes the 'illusory common interest' of a society" (Marx \& Engels 1965: 42 in Abrams 1988 [1977]: 64, emphasis in original). Abrams directs our attention to the word "illusory" and points out that the state is illusory not 


\section{Introduction}

because it is some reality or entity hidden behind a mask but because it is the mask. The ideological power of the state is exerted through the state's active work of masking and mystifying itself. As such, the key task to study state, according to Abrams, is to unravel the ways in which the state is masked and mystified and thus "illusory" (ibid.: 72).

In the Chinese context, one specific way for the Chinese state to exercise its ideological power is through the technology of uncertainty. The shifting boundaries of state-sanctioned activism is a very crucial part of the mystification of the Chinese state leaving the labor NGOs in a constant state of anxiety and frustration. Moreover, the uncertain limits of state tolerance about labor activism consequently lead to particular discourses and forms of practices that the labor NGOs employ to deal with the state, which illustrates how state power is exercised through the elusive boundary between the state and society. The uncertainty about the state - what the state wants, knows, and thinks - brings into sharp focus where the state appears to be both as a material force and an ideological construct (Mitchell 1991). More importantly, the uncertainty about the state tolerance becomes a powerful force that keeps the parameters of the NGO work in flux. These shifting parameters and the consequent practices to manage them-a form of self-censorship - are the specific work of state power. So through the idea of uncertainty, I show how this internal line between the state and society is drawn as Mitchell suggested. It is in the midst of uncertainty that one can start to discern the actual contours of the amorphous state and understand how state power works.

Hence, drawing on Abrams (1988 [1977]) and Mitchell (1991) in my theoretical discussion of uncertainty, I examine how the Chinese state is perceived, experienced, utilized, and mobilized by subjects located in the margins of the state. It is through the uncertainty at the margins of the Chinese state that I investigate the contingencies where boundaries and processes are instigated so as to facilitate certain relationships, distinct identities, and a particular mode of thinking, acting, and being. In these processes, the state and society are often treated as disparate and fixed entities so as to contingently justify and sustain certain discourses, forms, and practices. Rather than taking this distinction for granted, my analytical focus is to inquire into how the reification has come about and what effects and functions it has and serves because such contingent reification is the core of what makes the state-society relationship in contemporary China so dynamic and fraught with tension.

\section{Intimacy and complicity}

How does one locate and tease out such processes of contingent reification against the uncertainty of and about the state? I suggest that these contingent processes are to be located by studying a variety of practices, both discursive and performative, that have emerged from the domain of 
uncertainty. In my study, I trace how practices such as gossip, humor, irony, storytelling, guanxi (social relations), and secrecy are employed to gather and share information, apprehend incidents, and decipher signals from the state, as well as create and manage relationships in the labor community. These practices are studied in various social situations and encounters such as training workshops, staff meetings, outreach visits, office gossip, social media, mealtimes, and tea breaks. Simultaneously constituted by and constitutive of the associations of people, organizations, places, issues, and things with specific regard to the Chinese state, these practices are employed by labor activists to try to govern themselves in such a way to exist and operate without upsetting the Chinese state. In other words, these practices are exercised to navigate through the domain of uncertainty pivoted on the idea of the Chinese state.

Drawing inspiration from Pierre Bourdieu (1977, 1990), I see practice as a skillful manipulation of time and space that simultaneously acts in the present and draws on shared understandings from the past. My focus, however, is not to unearth and describe an internalized and unreflexive "habitus" but to illustrate the constant and reflexive manipulation of social options that results from a continual modification of and interplay between the temporal and spatial conditions, thus constituting "a practice of everyday life" (de Certeau 1984). Not only does this notion of practice allow me to discuss the temporal and spatial aspects of state control, but it also illustrates how the practices adopted by my research subjects articulate and embody sites of intimacy and complicity that have emerged from the domain of uncertainty. They are intimate because they are not readily available to the outsider; they are complicit because they are a necessary entailment of the state, a necessary component of the regime (Das \& Poole 2004: 4).

By "intimacy," I refer to the implicit knowledge and practices that constitute the sites that are straddling the line between official and vernacular, center and periphery, formal and informal, public and private, and inside and outside (Shryock 2004: 10-16). Michael Herzfeld has devoted much of his work to problematizing these distinctions, particularly with the concept of "cultural intimacy," defined as "the recognition of those aspects of an officially shared identity that are considered a source of external embarrassment but that nevertheless provide insiders with their assurance of common sociality" (2016: 7). The kind of intimacy is predicated on the presence of an outsider whose opinions and judgments are crucial to dictating what kind of value the common sociality can have (Shryock 2004: 10). While Herzfeld focuses on the emotional reaction of embarrassment, I would like to extend the idea of cultural intimacy to moments of self-recognition that trigger feelings of pride, superiority, empathy, solidarity, complicity, bitterness, and victimhood (cf. Shryock 2004: 11).

What is crucial in these moments is the acknowledgement of "an external observer whose opinion is imagined and imagined to matter" (Shryock 2004: 11, emphasis in original). As such, intimacy is understood against 
a background that foregrounds the experience of difference and "orients that experience toward the task of ranking, comparing, accommodating, impressing, persuading, or excluding an 'audience' of real and imaginary onlookers" (ibid., emphasis in original). Intimacy is not only the outcome of a response to the presence of the state but also a response to power (Kiossev 2002: 165-190). It is this extended understanding of intimacy that I employ in my analysis and in which I locate the sites of intimacy in the webs of relationships as well as discursive and performative practices of self-representation in the community of labor NGOs, workers, donors, and the Chinese state. More importantly, these practices are "ultimately dual, consisting both of what the outside observer can see and of the actors' understanding of what they are doing. The duality, not the intentionality alone, sets the problem for social science" (Pitkin 1972: 261, emphasis in original). Hence, the knowledge of the sites of intimacy and the practices employed to demarcate their boundaries have to be shared and expressed implicitly within the community in order to keep these sites productive of sociality and solidarity, which, in turn, is open for manipulation and creates a "community of complicity" (Steinmüller 2013).

To investigate the ways in which these practices and their intended functions are manifested in these meetings and encounters is also to understand how identity politics and the discourse of rights are played out among these actors who often need to strategically position themselves in relation to one another. In other words, these social situations call forth particular performative practices to form and communicate such identities as a "rights defender," a "social service provider," a "rule-abiding citizen," and a "victim of state violence." When the limits of state tolerance are unclear, the performance, negotiation, and sometimes reinforcement of the stereotypes of these different identities can become an essential survival strategy for these actors.

For labor NGOs and activists, the labor invested to gauge the limits of state tolerance can be examined by their use of certain words, their understanding of abstract concepts, and their everyday practices of enacting, reinforcing, or distancing the work that these words and concepts do, which, in turn, produce specific logics, engender discernible political effects, and regulate political behavior. I do not suggest that there are hidden and predetermined logics waiting to be uncovered and thus can lead us to predict and know the actors' intentions. Quite the contrary, my use of "logics" signifies how words, concepts, and practices make sense in specific contexts. The intelligibility of logics "comes from the ways in which language and institutions are embedded in a social world of iterative actions and performative practices" (Wedeen 2008: 15). Understood as actions repeated over time, practices are learned, reproduced, and subjected to risk because their iteration creates possibilities for intervention, action, improvisation, and subversion (de Certeau 1984; Butler 1993, 1997; Bourdieu 1977, 1990, 1991). For practices to be intelligible to others, they are dependent on contexts in the 
sense that they presuppose rules, norms, and conventions shared; freedom exercised; and responsibility entailed.

The practices described and discussed in this study are pivoted on the idea of mingan (敏感), which is usually translated as "sensitive" in English. In the context of this study, mingan, according to my research subjects, almost always refers to what is so politically sensitive as to engender unwanted risks and consequences. To gauge the limits of state tolerance of labor activism is to perceive and articulate the idea of mingan properly in order to maintain the appropriate distance from the state; it is also to strategically capitalize on the idea of mingan in order to, for example, create new partnerships. All of this is what I call the politics of mingan, which is the subject of Chapter 4. The ability to estimate and take advantage of the boundaries of the politically permissible embodies a kind of tacit knowledge (Polanyi 1958, 1966; Scott 1990) that is acquired through hands-on experiences and informal interactions among different actors. In this sense, tacit knowledge is also a type of intimate knowledge that is shared and circulated informally against formally instituted censorship. This type of knowledge leads to certain day-to-day practices, which are essential to the survival and development of the labor NGOs and is often mediated through gossip, rumor, humor, and irony. Moreover, to be able to adequately negotiate the politics of mingan is also an exercise of discretion. Lilith Mahmud discusses how the logic and practice of discretion is an important element of the world of Freemasons in contemporary Italy, which is frequently depicted as the quintessential Western secret society. Mahmud says that "[d]iscretion required an understanding that objects are at the same time in plain sight and hidden from the view [...] but only the correctly conjured public has the knowledge necessary [...] to decipher, to participate, to see" (Mahmud 2014: 30). In Chapter 4, I situate the politics of mingan in a workshop where the labor NGOs and donors met and discuss how the notion of mingan is played out, enacted, and received by a specific public that is in the know.

In the prefatory description of my meeting with Mandy, her commentary on her work touches upon the politics of mingan and indicates that some tacit knowledge and practices are required for her to manage projects and partnerships with the labor NGOs in mainland China. One such practice is the performance of secrecy. As Mandy noted, her Hong Kong-based NGO is so sensitive that certain things need to be kept secret. Her words crystalize the nexus between the politics of mingan and the practice of secrecy, revealing how these labor NGOs and foreign donors try to manage relationships with one another when dealing with government surveillance. As such, the practice of secrecy, which will be discussed in Chapter 5, embodies a space of intimacy in which discretion and complicity are exercised to uphold its boundaries by determining, for example, what things should be kept secret and how they are circulated within the labor community. I argue that the performative practice of secrecy, particularly public secrecy, is not only a practice of navigating through government surveillance but, more crucially, 
an essential performative practice of fostering trust among these social actors and of understanding the workings of state power.

\section{Outline of the chapters}

Chapter 1 addresses the methodology of this study and how I locate and study the field of uncertainty through multisited fieldwork and fieldwork as a research design process. I discuss the notions of NGO and civil society and how they are used and analyzed in my study. I also describe and reflect on the conditions of my fieldwork, the processes of negotiating access to and locating the field, and my own positionality. Against the backdrop of an authoritarian regime where civil liberties are limited and state surveillance is in operation, I discuss how I have come to use gossip as an ethnographic practice to manage my relationships with my interlocutors.

In Chapter 2, I give an account of the historical context of the emergence of labor NGOs in South China. It describes how an ethos of uncertainty, ambiguity, and indeterminacy has arisen in the wake of the economic reforms introduced in the late 1970s that have created the political, economic, and legal circumstances under which the labor NGOs emerged. Accompanying the economic growth was an increasing number of social organizations in the post-Mao era. By focusing on how labor NGOs struggle to become economically viable, I discuss the involvement of the international community via the mediation of Hong Kong labor groups. The political system will be described in particular with regard to the state secrets system and state surveillance in China.

In Chapter 3, I discuss how the notion of uncertainty is manifested in the day-to-day work of the labor NGOs and their relationships with their partners in Hong Kong as well as with the state. I show how uncertainty can be conceptualized as a notion that is productive in making certain relationships and practices possible. These relationships and practices occupy an analytical and ethnographic space, which is constitutive of the ways in which governance works in China and can be understood through such concepts as intimacy, complicity, secrecy, and mingan, which will be closely examined ethnographically in the ensuing chapters.

In Chapter 4, I discuss the local understanding and usage of the concept of mingan which is not only used as a guiding principle in the day-to-day work of the NGOs but is also a constitutive part of the uncertainty of the political environment. Mingan is conceptualized as a productive notion whereby impressions can be managed and resources can be mobilized. I use the example of a workshop in Beijing in which the NGOs tried to mobilize around and capitalize on the notion of mingan when interacting with foreign funding agencies.

With the notion of secrecy, Chapter 5 discusses the partnerships among the labor NGOs in mainland China and Hong Kong. Despite the fact that the practice of secrecy is very much informed by state surveillance, I argue 
that the performance of secrecy is not so much about managing their relationship with the Chinese state as it is with managing the relationships among the NGOs. Secrecy is productive in the sense that it is utilized to foster sociality, solidarity, and, most important of all, trust among these NGOs.

In Chapter 6, I discuss the implementation of a development program in order to show specifically how the aforementioned skills, practices, and knowledge of navigating the uncertain political terrains are applied in a particular context. Two ethnographic examples (two labor NGOs) are used in this chapter, which serve as contrasting examples to illustrate the success as well as failure in carrying out the program. The chapter ends with an ethnographic anecdote that shows that despite acquiring the necessary skills and doing the right things as perceived by the NGOs themselves, the NGOs still encountered harassment from the government. With this, this chapter brings the reader back to the notion of uncertainty and further reinforces the uncertain conditions under which these NGOs exist. In the conclusion, I return to the notions of uncertainty, intimacy, and complicity, and discuss how they affect my production of knowledge about the labor community in South China. More importantly, I argue how these notions provide an entry point to a more nuanced understanding of the workings of the Chinese state.

\section{Notes}

1 In this study, I use "mainland China" and "the mainland" interchangeably; both specifically refer to the geographical area under the direct jurisdiction of the People's Republic of China and exclude the Special Administrative Regions of Hong Kong and Macau. The distinction is important in the context of this study. There are two terms in Chinese for "mainland": One is dalu (大陆), which means continent, and the other is neidi (内地), which means inland or inner land.

2 In his study of the Chinese Communist Party's Central Publicity Department (CPD), Hassid (2008) argues that CPD has absolute power to determine what is appropriate media coverage. What is frustrating for the Chinese news workers is that what qualifies as appropriate news coverage is not always clear. In fact, all too often the boundaries of suitable news stories are so vague and arbitrary that many media workers have to exert critically more self-censorship in order to stay within the vaguely defined boundaries of state tolerance.

1 The director of South Mountain was under a lot of pressure from the local police, who had gone so far as to harass his family in Shanxi Province in North China. He then decided to leave the NGO.

1 For example, a provision was put in place in the 1990s that allowed rural residents to purchase temporary urban residency permits so that they could work and live legally in the cities. Since the 2000s, the hukou system has been further weakened. In 2003, migrant worker Sun Zhigang was taken to a detention center after being unable to produce his temporary residency permit and identity card when he was stopped by the police. Sun Zhigang suffered physical abuse while being detained and died of the severe injuries from the beatings in the detention center. His death sparked wide protests across the country and led to the government's repeal of the laws regarding the arrest and repatriation of migrant workers found illegally living and working in the cities (Liang 2011: 83-102). 
2 The word henhei literally means very black. In this context, it refers to the underhanded tactics of the village committee.

3 This interview was conducted in May 2013.

4 The names of the labor NGOs mentioned here are all authentic.

5 GONGOs are government-sponsored NGOs that may resemble an NGO. GONGOs are usually created for the purpose of promoting issues that the government wants to bring attention to. GONGOs can also be created in order to qualify for outside aid or to mitigate specific issues related to certain aspects of domestic affairs or international relations.

6 Mary Gallagher has noted that although the national statistics showed there was a rapid increase in labor disputes in the mid-1990s, it is not entirely clear what this increase signifies. She suggests the rise in labor disputes could result from the lack of legal regulation of labor prior to the reform era so the rate of increase is from an extremely low base point (2007 [2005]: 116).

7 The exchange the rate was 6.66 RMB per dollar during the time of my fieldwork.

8 The story of Liu Xiaowen, which is a pseudonym, was gathered from the blog of Green Grass and my interviews with labor NGO activists. For reasons of confidentiality, I will not provide the link to the blog.

9 More information on the new amendment is available at http://baike.baidu.com/ view/703598.htm accessed August 27, 2019.

10 From: www.gov.cn/zwgk/2014-02/03/content_2579949.htm accessed August 27, 2019

11 From: www.gov.cn/flfg/2010-04/30/content_1596420.htm accessed August 27, 2019.

12 Information on the different types of state secrets is available at www.gov.cn/ flfg/2010-04/30/content_1596420.htm, accessed August 27, 2019.

13 Finder, Susan. 2014. How China classifies state secrets. The Diplomat, December 23. Available at: http://thediplomat.com/2014/12/how-china-classifies-statesecrets/ accessed March 9, 2015.

14 Guobao is a shorthand for the Domestic Security Department of the Public Security Bureau. It is a branch of the police force within the Ministry of Public Security, which is responsible for and specializes in collecting intelligence and infiltrating and dealing with political dissidents, human rights activists, petitioners, religious groups, and others engaged in "subversive" activities.

15 He was referring to the crackdown in 2012, which will be discussed in detail in the next chapter.

16 The frequency of the visits by the state security agents seems to vary, and it is not easy to infer whether such factors as the location of the NGO and the services provided by the NGO determine the frequency of these visits. For example, some labor NGOs in Guangzhou City have visits almost once a week or every other week.

17 This interview was conducted in January 2013.

18 This interview was conducted in Februray 2013.

19 Buckley, Chris. 2011. China Internal Security Spending Jumps Past Army Budget. Reuters, March 5. Available at: www.reuters.com/article/us-chinaunrest-idUSTRE7222RA20110305 accessed October 30, 2014.

20 My discussion on the funding received by the Chinese labor NGOs can also be read in my chapter titled "Thinking like a state: doing labor activism in South China" in Handbook of protest and resistance in China, edited by Teresa Wright (2019: 151-165).

21 The names of the NGOs in Hong Kong are all authentic.

22 The interview with the Hong Kong NGO worker was conducted in May 2013. The word "sensitive" here is used to refer to something that is politically sensitive and risky. In Chapter 5, I will discuss this issue in more detail.

23 This interview was conducted in June 2013. 
1 The strike started on May 17, 2010 when workers and interns at the Nanhai Honda Auto Parts Manufacturing Company in Foshan, Guangdong province, staged a walkout demanding a significant wage increase. Gradually, the strike had spread to other Honda plants in the country and had paralyzed production of four plants in China. The strike lasted 19 days, and 1900 workers were estimated to have participated in the strike. The workers obtained the wage rise they demanded and were promised that they would be able to elect their own trade union committee.

2 My discussion and analysis of the crackdown in 2012 was published in my chapter "Thinking like a state: doing labor activism in South China." In Handbook of protest and resistance (2019), edited by Teresa Wright. Cheltenham, UK: Edward Elgar Publishing, pp. 151-165.

3 The names of the individuals mentioned in the discussion of the 2012 crackdown are all pseudonyms. When citing news reports as well as public support campaigns about the suppressed NGOs, I do not change the names of these NGOs and use the names as they appear in these public documents. This interview was conducted in January 2013.

4 Standaert, Michael. 2012. Labor NGOs face tough times in Guangdong; group alleges child labor, corruption in factory audits. Bloomberg BNA, August 16. Available at: www.workerempowerment.org/en/media-coverage/46 accessed on May 20, 2014.

5 From: www.workerempowerment.org/en/updates/36 accessed on April 24, 2015.

6 Unnamed author. 2012. Support Chinese Labor NGOs (聲援中國勞工維權組織). Inmediahk, December 12. Available at: www.inmediahk.net/node/1014958 accessed on April 23, 2015; unnamed author. 2012. Stop the crackdown on labor NGOs in China. Talking Union, October 17. Available at: https://talkingunion. wordpress.com/2012/10/17/stop-the-crackdown-on-labour-ngos-in-china/ accessed on April 24, 2015; unnamed author. 2012. China: stop the crackdown on labor NGOs. Good electronics, October 15. Available at: http://goodelectronics.org/ news-en/china-stop-the-crackdown-on-labour-ngos accessed on May 22, 2014.

7 Since this is an event that has been reported on in the media and circulated on Chinese social media, I use the real name of the labor NGO, shown in parenthesis, and provide an English translation. The story of how this labor NGO was unjustly and violently treated by the authorities was widely reported and circulated. See www.rfa.org/cantonese/news/ngo-08312012092248.html accessed April 20, 2013.

8 Unnamed author. 2012. Government crackdown on labor groups worsens in South China. Public Radio International, September 2. Available at: www. globalpost.com/dispatch/news/regions/asia-pacific/china/120831/south-chinalabor-crackdown accessed on May 20,2013. The video is no longer available on the Internet.

9 Little Grass posted a lot of information on their blog and website about how they were suppressed by the local authorities. http://bbs.tianya.cn/post-838-33197-1. shtml accessed on April 23, 2013.

10 In fact, the crackdown started in late 2011 but was not reported in the media until 2012. Dagongzhe Migrant Workers' Center is believed to be the first victim of the crackdown. The labor NGO posted a chronology of the government harassment on their blog (http://blog.sina.com.cn/s/blog_6b0ef6fc01013mlp.html accessed on May 22, 2014.) But the entry has been deleted later and is no longer available.

11 The discussion of how the labor NGOs and activists develop different theories about the crackdown was published in my chapter "Thinking like a state: doing labor activism in South China." In Handbook of protest and resistance (2019), edited by Teresa Wright. Cheltenham, UK: Edward Elgar Publishing, pp. 151-165.

12 Unnamed author. 2012. Shenzhen Party Secretary Wang Rong supports Jiang Party platform and attracts enmity from Wang Yang (深圳市委书记王荣为江 派站台与汪洋结怨). Epoch Times, June 16. Available at: www.epochtimes.com/ $\mathrm{gb} / 12 / 6 / 16 / \mathrm{n} 3613795 . h t m$ accessed on June 25, 2014. 
13 Guangdong has invested a lot of resources into its project to enhance the role of social organizations in building a harmonious society. One of the policy objectives is to establish as many social service centers as possible. In Guangzhou, the goal is that each street will have one social service center with a budget of two million RMB to provide their services.

14 The Federation of Social Service Organizations for Guangdong Workers was announced and created on May 16, 2012 in Guangzhou. This Federation was initiated and is led by the ACFTU of Guangdong Province. It encourages workeroriented individuals, research institutes, and social service organizations to join. According to the website of the ACFTU of Guangdong Province, the Federation currently consists of 34 organizations and 55 individual members. More information is available at www.gov.cn/gzdt/2012-05/17/content_2139311.htm accessed on June 3, 2014.

15 As I found out later, the director of this Hong Kong labor NGO had regular meetings with the officials from the Guangdong ACFTU.

16 From the Department of Civil Affairs of Guangdong Province. www.gdnpo.gov. cn/home/index/newsview/m8le3144483 accessed on February 28, 2016.

17 The regulation on social organizations has been updated since it was implemented in 2012. The link here is the updated version from 2015: www.gd.gov.cn/ zwgk/zcfgk/content/post_2531906.html accessed on February 28, 2016.

18 This interview was conducted in April 2013.

19 The name of the university is authentic.

20 Unnamed author. 2012. Guangdong uses new policy to suppress dissident social organizations (广东借新政策打压异见社会组织). Radio Free Asia, August 20. Available at: www.rfa.org/cantonese/features/hottopic/feature_ngo08202012120313.html accessed on February 28, 2016.

21 The interview was conducted in May 2013.

22 The interview was conducted in May 2013.

1 References on the translation of the word mingan can be found at, for example, the Contemporary Chinese Dictionary (Chinese-English edition) and Baidu, China's biggest search engine: https://fanyi.baidu.com/translate\#zh/ en $/ \% \mathrm{E} 6 \% 95 \% 8 \mathrm{~F} \% \mathrm{E} 6 \% 84 \% 9 \mathrm{~F}$ accessed on June 20, 2015.

2 This conversation took place in July 2013.

3 The interview was conducted in May 2013.

4 Unnamed author. 2014. Thousands of China workers on strike. BBC, April 17. Available at: www.bbc.com/news/business-27059434 accessed September 19, 2014.

5 This conversation took place in March 2013.

6 I will talk more about this National Congress in Chapter 5, which deals with the subject of secrecy.

7 The interview was conducted in June 2013.

8 Fang, Lan. 2013. International humanitarian aid re-positioned (重新定位 国际援助). Caixin, February 22. Available at: http://m.magazine.caixin. com/m/2013-02-22/100493238.html accessed July 26, 2015.

9 The Chinese term "tai lihai" literally means "very good at or capable of doing something very well." Here, I have translated the term as "progressive" because that is what was referred to in this context. The focus was on the NGOs" capability for being progressive and critical of the government.

10 The interview was conducted in March 2013.

1 It is worth mentioning that at this stage in my fieldwork I had not been in any contact with CWF. Having heard so much about CWF through their partners in China and how sensitive it is to work with CWF according to the Chinese labor NGOs, I had been waiting for such a meeting. The workshop presented a great opportunity for me to meet CWF.

2 In the next chapter, I will talk more about the meaning and application of collective bargaining in China and how it is different from mainly Western contexts. 
3 Shenzhen and Hong Kong share a border, so it is very convenient to travel between these two cities. One can go by airplane, train, bus, or ferry. Taking the train is one of the most popular ways and it takes about one hour and a half. There are a number of entry points between these two cities depending on one's destination within the city. When traveling from Shenzhen to Hong Kong, many people take the subway to the district of Luohu, cross customs and take the subway again, which goes all the way to downtown Hong Kong.

4 Subler, Jason. 2012. Ready, steady, go for China Congress, not marathon runner. Reuters, September 5. Available at: www.reuters.com/article/us-china-congressidUSBRE8840FS20120905 accessed March 31, 2016.

5 The passage was taken from an interview I had with Mandy in June 2013.

6 Unnamed author. 2013. Wire-tapping wars: the world of official espionage. China Digital Times, February 17. Available at: http://chinadigitaltimes.net/2013/02/ wiretapping-wars-the-world-of-official-espionage/ accessed March 29, 2016.

7 The passage was taken from an interview I had with Mandy in June 2013.

8 A famous example is the spamming campaigns of Xiao Cankao (VIP Reference), a Washington D.C.-based Chinese-language online publication. Founded in November 1997, Xiao Cankao publishes articles from Hong Kong, Taiwan, and Western news sources that are not available to the public in China. As a countermeasure to protect readers and obstruct the Chinese government's efforts to prevent users in mainland China from accessing their publication, Xiao Cankao provides a degree of "plausible deniability" to their subscribers by spamming numerous copies to recipients who have not requested them (Chase \& Mulvenon 2002: 31). Moreover, the editors of Xiao Cankao frequently change web addresses and use a different email address every day to thwart Chinese security services' attempts to block the electronic distribution of their publication (ibid.).

9 The passage was taken from an interview I had with Mark in June 2013.

10 The term was coined by Geremie R. Barmé and Sang Ye in their article titled: "The Great Firewall of China," Wired 5.06, June 1997. Available at: http:// archive.wired.com/wired/archive/5.06/china.html accessed April 7, 2015.

11 More information on receiving foreign funds is available here: www.safe.gov.cn/ safe/glxx1/index.html accessed January 29, 2019.

12 Richburg, Keith B. 2010. China's crackdown on non-profit groups prompts new fears among activists. The Washington Post, May 11. Available at: www. washingtonpost.com/wpdyn/content/article/2010/05/10/AR2010051004801.html accessed April 1, 2015; Jackson-Han, Sarah. 2010. NGOs face tighter curbs. Radio Free Asia, April 21. Available at: www.rfa.org/english/news/china/ngo04212010124252.html accessed April 1, 2015.

13 The passage was taken from an interview I had with Mandy in June 2013.

14 The passage was taken from an interview I had with Mandy in June 2013.

15 One staff member of Little Flower didn't know that her organization was in partnership with CWF after having worked there for almost a year.

16 Traveling with his passport meant that Wu Xiangjun was only passing through Hong Kong en route to somewhere else. According to the regulation, he was allowed to stay in Hong Kong for seven days during transit.

17 The passage was taken from an interview I had with Wu Xiangjun in April 2013.

18 The passage was taken from an interview I had with Wu Xiangjun in April 2013.

19 The passage was taken from an interview I had with Mandy in June 2013.

20 The passage was taken from an interview I had with Mandy in June 2013.

21 From: www.oecd.org/dac/effectiveness/45827300.pdf accessed February 10, 2020.

22 The passage was taken from an interview I had with Mark in June 2013.

23 The passage was taken from an interview I had with Mark in June 2013.

1 This section was published in "Agents of change or status quo? Labor NGOs in South China." In Uncertain times: anthropological approaches to labor in a neoliberal world, edited by E. Paul Durrenberger. Boulder: University Press of 
Colorado, pp. 135-160.

2 The distinction between mainland China and Hong Kong is made to illustrate the difference between Chinese people who have settled in Hong Kong for a generation or more and Chinese people who have just come to Hong Kong to study or work. The latter group is popularly called "new immigrants" by the residents in Hong Kong.

3 South Mountain was closed down as a result of government repression in 2015.

4 "Status" refers to Liao Yumin's residence permit. The police wanted to know if Liao Yumin had official permission to live in the city.

5 Advice on how to deal with state security agents when one is arrested is popularly disseminated on the Internet, especially on social media. The link below is an example: A lawyer posted the standard procedures for dealing with the police and what rights a person has when being taken to the police station. http:// mp.weixin.qq.com/s?__biz=MzA5NTMxNjcxMQ==\&mid=200365043\&idx$=1 \& \mathrm{sn}=3 \mathrm{f} 3 \mathrm{df} 913 \mathrm{a} 0 \mathrm{~b} 87 \mathrm{eae} 9050 \mathrm{be} 0886 \mathrm{aca} 2 \mathrm{f} 8 \&$ scene $=2 \&$ from $=$ timeline $\&$ isap pinstalled $=0 \&$ key $=\mathrm{d} 7 \mathrm{e} 970 \mathrm{edec} 361 \mathrm{a} 55 \mathrm{a} 624 \mathrm{~b} 29 \mathrm{bb} 08 \mathrm{a} 5 \mathrm{e} 7 \mathrm{~b} 69247767 \mathrm{ab} 65 \mathrm{c} 83 \mathrm{~b}-$ d82a $8 \mathrm{cdf} 405824868 \mathrm{afbd} 3108 \mathrm{cf} 4416 \mathrm{~b} 6 \mathrm{~d} 756 \mathrm{a} 2 \mathrm{a} 7 \mathrm{~b} 845188 \&$ ascene $=2 \&$ uin $=\mathrm{M}-$ jI2NDEwNTE1OA\%3D\%3D accessed April 15, 2016.

6 Some discussions of this successful case have been published in "Agents of change or status quo? Labor NGOs in South China." In Uncertain times: anthropological approaches to labor in a neoliberal world, edited by E. Paul Durrenberger. Boulder: University Press of Colorado, pp. 135-160.

7 Contributions need to be made over a number of years in order to grant eligibility for benefits: 15 years for the pension program, and at least one year for unemployment insurance.

8 It can be $50 \mathrm{RMB}$ or $100 \mathrm{RMB}$ per person. The fund is managed by a worker selected by the workers themselves.

9 The passage was taken from an interview I had with Zhang Guoqi in May 2013.

10 Some parts of the conclusion have been published in "Agents of change or status quo? Labor NGOs in South China." In Uncertain times: anthropological approaches to labor in a neoliberal world, edited by E. Paul Durrenberger. Boulder: University Press of Colorado, pp. 135-160. 


\section{Bibliography}

Abrams, Philip. 1988 [1977]. Notes on the difficulty of studying the state. Journal of Historical Sociology 1 (1): 58-89.

Adams, John. 1997. "Cars, cholera, cows, and contaminated land: virtual risk and the management of uncertainty." In What risk? edited by Roger Bate. Oxford: Butterworth-Heinemann, pp. 285-314.

Bayart, Jean-Francois. 1993 [1989] The state in Africa: the politics of the belly. New York: Longman.

Beck, Ulrich. 1992. Risk society: toward a new modernity. New York: Sage Publications.

Benedict, Ruth. 2005 [1934]. Patterns of culture. Boston, MA: Houghton Mifflin.

Bernal, Victoria. 1997. Colonial moral economy and the discipline of development: the Gezira scheme and "Modern" Sudan. Cultural Anthropology 12 (4): 447-479.

Boholm, Åsa. 2003. The cultural nature of risk: can there be an anthropology of uncertainty? Ethnos 68 (2): 159-178.

Bourdieu, Pierre. 1991. Language and symbolic power. Translated by Gino Raymond and Matthew Adamson. Cambridge, MA: Harvard University Press.

1990. The logic of practice. Translated by Richard Nice. Cambridge: Polity Press.

1977. Outline of a theory of practice. Translated by Richard Nice. Cambridge: Cambridge University Press.

Butler, Judith. 1997. Excitable speech: a politics of the performative. New York: Routledge.

1993. Bodies that matter: on the discursive limits of "sex." New York: Routledge.

Cancian, Frank. 1980. "Risk and uncertainty in agricultural decision making." In Agricultural decision making: anthropological contributions to rural development, edited by Peggy F. Barlett. Orlando, FL: Academic Press, pp. 161-176.

Cashdan, Elizabeth. ed. 1990. Risk and uncertainty in tribal and peasant economies. Boulder, CO: Westview Press.

Chan, Anita. 2001 China's workers under assault: the exploitation of labor in a globalizing economy. New York: M.E. Sharpe.

Chang, Gordon G. 2001. The coming collapse of China. New York: Random House.

Cohn, Bernard S. 1996. Colonialism and its forms of knowledge: the British in India. Princeton, NJ: Princeton University Press.

Comaroff, John L. 1998. Reflections on the colonial state, in South Africa and elsewhere: factions, fragments, facts, and fictions. Social Identities 4 (3): 321-361.

Coronil, Fernando. 1997. The magical state: nature, money, and modernity in Venezuela. Chicago: University of Chicago Press.

Das, Veena. 1995. Critical events: an anthropological perspective on contemporary India. Delhi: Oxford University Press.

Das, Veena, and Deborah Poole, eds. 2004. Anthropology in the margins of the state: comparative ethnographies. Santa Fe: School of American Research Press.

De Certeau, Michel. 1984. The practice of everyday life. Berkeley: University of California Press.

Deleuze, Gilles. 1994. Difference and repetition. Translated by Paul Patton. London: Athlone.

deLisle, Jacques. 2004. Atypical pneumonia and ambivalent law and politics. Temple Law Review 77: 193-245.

Derrida, Jacques. 1997. The politics of friendship. Translated by George Collins. London: Verso. 
1994. Specters of Marx: The state of the debt, the work of mourning, and the new international. Translated by Peggy Kamuf. New York: Routledge.

1978. Writing and difference. Translated by Alan Bass. London: Routledge.

1976. Of grammatology. Translated by Gayatri Chakravorty Spivak. Baltimore, MD: Johns Hopkins University Press.

Dillon, Nara. 2011. "Governing civil society: adapting revolutionary methods to serve post-communist goals." In Mao's invisible hand: the political foundations of adaptive governance in China, edited by Sebastian Heilmann and Elizabeth J. Perry. Cambridge, MA: Harvard University Asia Center, pp. 138-164.

Douglas, Mary, and Aaron Wildavsky. 1982. Risk and culture: an essay on the selection of technical and environmental dangers. Berkeley: University of California Press.

Duara, Prasenjit. 1987. State involution: a study of local finances in North China, 1911-1935. Comparative Studies in Society and History 29 (1): 132-161.

Elyachar, Julia. 2005. Markets of dispossession: NGOs, economic development, and the state in Cairo. Durham, NC: Duke University Press.

Ferguson, James, and Akhil Gupta. 2002. Spatializing states: toward an ethnography of neoliberal governmentality. American Ethnologist 29 (4): 981-1002.

Foucault, Michel. 2002 [1969]. The archaeology of knowledge. Translated by A. M. Sheridan Smith. London: Routledge.

2002 [1970]. The order of things: an archaeology of the human sciences. London and New York: Routledge.

1992 [1978]. The history of sexuality. Vol. 2: the use of pleasure. Translated by Robert Hurley. New York: Penguin Books.

1984. The Foucault reader. Edited by Paul Rabinow. New York: Pantheon.

Geertz, Clifford. 2004. What is a state if it is not a sovereign? Reflections on politics in complicated places. Current Anthropology 45 (5): 577-593.

2000 [1973]. "Deep play: notes on the Balinese cockfight." In The interpretation of cultures. New York: Basic Books, pp. 412-453.

1969 [1963]. Agricultural involution: the processes of ecological change in Indonesia. Berkeley: University of California Press.

Giddens, Anthony. 2000. Runaway world: how globalization is reshaping our lives. New York: Routledge.

Gilley, Bruce. 2004. China's democratic future: how it will happen and where it will lead. New York: Columbia University Press.

Gupta, Akhil. 2012. Red tape: bureaucracy, structural violence, and poverty in India. Durham, NC: Duke University Press.

Hansen, Thomas Blom, and Finn Stepputat, eds. 2001. States of imagination: ethnographic explorations of the postcolonial sate. Durham, NC and London: Duke University Press.

Hassid, Jonathan. 2010. Pressing back: the struggle for control over China's journalists. PhD dissertation, University of California, Berkeley.

2008. Controlling the Chinese media: an uncertain business. Asian Survey 48 (3): 414-430.

Heilmann, Sebastian, and Elizabeth J. Perry, eds. 2011. Mao's invisible hand: the political foundations of adaptive governance in China. Cambridge, MA: Harvard University Asia Center.

Herzfeld, Michael. 2016. Cultural intimacy: social poetics and the real life of states, societies, and institutions. New York: Routledge.

Hull, Matthew S. 2012. Government of paper: the materiality of bureaucracy in urban Pakistan. Berkeley: University of California Press. 
James, Wendy, ed. 1995. The pursuit of certainty: religious and cultural formulations. London: Routledge.

Joseph, Gilbert M., and Daniel Nugent, eds. 1994. Everyday forms of state formation: revolution and the negotiation of rule in rural Mexico. Durham, NC: Duke University Press.

Kiossev, Alexander. 2002. "The dark intimacy: maps, identifications, acts of identifications." In Balkan as metaphor: between globalization and fragmentation, edited by Dušan I. Bjelić and Obrad Savić. Cambridge, MA: MIT Press, pp. 165-190.

$\mathrm{Ku}$, Hok Bun. 2003. Moral politics in a South China village: responsibility, reciprocity, and resistance. Lanham, MD: Rowman \& Littlefield.

Latour, Bruno. 2005. Reassembling the social: an introduction to actor-networktheory. Oxford: Oxford University Press.

Lee, Ching Kwan. 2010. "Workers and the quest for citizenship.” In Reclaiming Chinese society: the new social activism, edited by You-tien Hsing and Ching Kwan Lee. London and New York: Routledge, pp. 42-63.

2007. "Is labor a political force in China?" In Grassroots political reform in contemporary China, edited by Elizabeth J. Perry and Merle Goldman. Cambridge, MA: Harvard University Press, pp. 228-252.

Lévi Strauss, Claude. 1963 [1958]. Structural anthropology. London: Allen Lane.

Levy, Richard. 2007. "Village elections, transparency, and anti-corruption: Henan and Guangdong provinces." In Grassroots political reform in contemporary China, edited by Elizabeth J. Perry and Merle Goldman. Cambridge, MA: Harvard University Press, pp. 20-47.

Link, Perry. 2002. China: the anaconda in the chandelier. New York Review of Books. Available at: www.nybooks.com/articles/2002/04/11/china-theanaconda-in-the-chandelier/ accessed December 11, 2015.

Litzinger, Ralph. 2007. "In search of the grassroots: hydroelectric politics in Northwest Yunan.” In Grassroots political reform in contemporary China, edited by Elizabeth J. Perry and Merle Goldman. Cambridge, MA: Harvard University Press, pp. 282-299.

Liu, Xin. 2000. In One's own shadow: an ethnographic account of the condition of post-reform rural China. Berkeley: University of California Press.

Lu, Xiaobo. 2000. Cadres and corruption: the organizational involution of the Chinese Communist Party. Stanford: Stanford University Press.

Luhmann, Niklas. 1993. Risk: a sociological theory. New York: Aldine de Gruyter.

Mahmud, Lilith. 2014. The brotherhood of Freemason sisters: gender, secrecy, and fraternity in Italian Masonic lodges. Chicago: University of Chicago Press.

Malinowski, Bronislaw. 1944. A scientific theory of culture and other essays. Chapel Hill: University of North Carolina Press.

Marx, Karl and Friedrich Engels. 1965. The German ideology. London: Lawrence \& Wishart.

McNally, Christopher A. 2011. China's changing guanxi capitalism: private entrepreneurs between Leninist control and relentless accumulation. Business and Politics 13 (2), article 5: 1-29.

Mitchell, Timothy. 1999. "Society, economy, and the state effect." In State/Culture: state formation after the cultural turn, edited by George Steinmetz. Ithaca, NY: Cornell University Press, pp. 76-97.

1991. The limits of the state: beyond statist approaches and their critics. The American Political Science Review 85 (1): 77-96.

Moore, Sally Falk. 1987. Explaining the present: theoretical dilemmas in processual ethnography. American Ethnologist 14 (4): 727-736. 
Murphy, Rachel. 2007. The paradox of the state-run media promoting poor governance in China: case studies of a party newspaper and an anti-corruption film. Critical Asian Studies 39 (1): 63-88.

Nathan, Andrew J. 2003. Authoritarian resilience. Journal of Democracy 14 (1): $6-17$.

Nettle, J. P. 1968. The state as a conceptual variable. World Politics 20 (4): 559-592.

Niehaus, Isak. 2013. Confronting uncertainty: anthropology and zones of the extraordinary. American Ethnologist 40 (4): 651-660.

Nowotny, Helga. 2015. The cunning of uncertainty. Cambridge: Polity.

Nugent, David. 1997. Modernity at the edge of empire: state, individual, and nation in the northern Peruvian Andes, 1885-1935. Stanford: Stanford University Press.

O'Brien, Kevin J., and Lianjiang Li. 2006. Rightful resistance in rural China. New York: Cambridge University Press.

Ortner, Sherry B. 1984. Theory in anthropology since the sixties. Comparative Studies in Society and History 26 (1): 126-166.

Oxfeld, Ellen. 2010. Drink water, but remember the source: moral discourse in a Chinese village. Berkeley: University of California Press.

Pan, Darcy. 2019. "Thinking like a state: doing labor activism in South China." In Handbook of protest and resistance in China, edited by Teresa Wright. Cheltenham, UK: Edward Elgar Publishing, pp. 151-165.

2016. Laboring through uncertainty: an ethnography of the Chinese state, labor NGOs, and development. PhD dissertation, Stockholm University.

Pei, Minxin. 2006. China's trapped transition: the limits of developmental autocracy. Cambridge, MA: Harvard University Press.

Perry, Elizabeth J. 2002. Challenging the mandate of heaven: social protest and state power in China. New York: M. E. Sharpe.

Pitkin, Hanna Fenichel. 1972. Wittgenstein and justice: on the significance of Ludwig Wittgenstein for social and political thought. Berkeley: University of California Press.

Polanyi, Michael. 1966. The tacit dimension. Chicago: University of Chicago Press. 1958. Personal knowledge: towards a post-critical philosophy. London: Routledge \& Kegan Paul.

Radcliffe-Brown, A.R. 1987 [1940]. "Preface." In African political systems, edited by Meyer Fortes and E. E. Evans-Pritchard. London: Routledge \& Kegan Paul, Associated Book Publishers Ltd, pp. xi-xxiii.

1922. The Andaman islanders: a study in social anthropology. Cambridge: Cambridge University Press.

Riles, Annelise. ed. 2006. Documents: artifacts of modern knowledge. Ann Arbor: University of Michigan Press.

Rosa, Eugene A. 1998. Metatheoretical foundations for post-normal risk. Journal of Risk Research 1(1): 15-44.

Rose, Nikolas. 2008 [1999]. Powers of freedom: reframing political thought. Cambridge: Cambridge University Press.

1999 [1989]. Governing the soul: the shaping of the private self. London and New York: Free Association Books.

SACOM. 2005. Looking for Mickey Mouse's conscience: a survey on working conditions of Disney supplier factories in China. Available at: http://sacom.hk/wpcontent/uploads/2008/07/disney.pdf accessed September 15, 2015.

Sahlins, Marshall. 1985. Islands of history. Chicago: University of Chicago Press. 
Samimian-Darash, Limor, and Paul Rabinow. 2015. "Introduction." In Modes of uncertainty: anthropological cases, edited by Limor Samimian-Darash and Paul Rabinow. Chicago: University of Chicago Press, pp. 1-9.

Scott, James C. 1998. Seeing like a state: how certain schemes to improve the human condition have failed. New Haven, CT: Yale University Press.

1990. Domination and the arts of resistance: hidden transcripts. New Haven, CT: Yale University Press.

Sharma, Aradhana, and Akhil Gupta, eds. 2006. The anthropology of the state: a reader. Oxford: Blackwell Publishing.

Shirk, Susan L. 2007. China: fragile superpower. New York: Oxford University Press. Shryock, Andrew, ed. 2004. Off stage on display: intimacy and ethnography in the age of public culture. Stanford: Stanford University Press.

Shue, Vivienne. 2004. "Legitimacy crisis in China?" In State and society in 21st century China: contention and legitimation, edited by Peter Hays Gries and Stanley Rosen. New York: Routledge, pp. 24-49.

1988. The reach of the state: sketches of the Chinese body politic. Stanford: Stanford University Press.

Siu, Helen F. 1989a. Agents and victims in South China: accomplices in rural revolution. New Haven, CT: Yale University Press.

1989b. Socialist peddlers and princes in a Chinese market town. American Ethnologist 16 (2): 195-212.

Solinger, Dorothy J. 1999. Contesting citizenship in urban China: peasant migrants, the state, and the logic of the market. Berkeley: University of California Press.

Steinmetz, George, ed. 1999. State/Culture: state-formation after the cultural turn. Ithaca, NY: Cornell University Press.

Steinmüller, Hans. 2013. Communities of complicity: everyday ethics in rural China. New York: Berghahn Books.

Stern, Rachel E., and Jonathan Hassid. 2012. Amplifying silence: uncertainty and control parables in contemporary China. Comparative Political Studies 45 (10): $1230-1254$.

Stern, Rachel E., and Kevin J. O'Brien. 2012. Politics at the boundary: mixed signals and the Chinese state. Modern China 38 (2): 174-198.

Taussig, Michael. 1997. The magic of the state. New York: Routledge. 1992. The nervous system. New York: Routledge.

Trouillot, Michel-Rolph. 2003. Global Transformations: anthropology and the modern world. New York: Palgrave Macmillan.

Wedeen, Lisa. 2008. Peripheral visions: publics, power, and performance in Yemen. Chicago: University of Chicago Press.

$\mathrm{Xu}$, Bin, and Xiaoyu Pu. 2010. Dynamic statism and memory politics: a case analysis of the Chinese war reparations movement. The China Quarterly 201: 156-175.

Yang, Guobin. 2009. The power of the Internet in China: citizen activism online. New York: Columbia University Press.

2008. "Contention in cyberspace." In Popular protest in China, edited by Kevin J. O'Brien. Cambridge, MA: Harvard University Press, pp. 126-143.

Yang, Shu-Yuan. 2005. Imagining the state: an ethnographic study. Ethnography 6 (4): 487-516.

Bach, Jonathan. 2017. "They come in peasants and leaves citizens: urban villages and the making of Shenzhen." In Learning from Shenzhen: China's post-Mao experiment from special zone to model city, edited by Mary Ann O'Donnell, Winnie Wong, and Jonathan Back. Chicago: University of Chicago Press, pp. 138-170. 
2011. Modernity and the urban imagination in economic zones. Theory, Culture \& Society 28 (5): 98-122.

Béja, Jean-Philippe. 2006. The changing aspects of civil society in China. Social Research 73 (1): 53-74.

Bell, Colin. 1968. Middle class families: social and geographic mobility. London: Routlege.

Bergmann, Jörg R. 1993. Discreet indiscretions: the social organization of gossip. New York: Aldine De Gruyter.

Bernal, Victoria, and Inderpal Grewal, eds. 2014. Theorizing NGOs: states, feminisms, and neoliberalism. Durham, NC: Duke University Press.

Besnier, Niko. 2009. Gossip and the everyday production of politics. Honolulu: University of Hawaii Press.

Bratton, Michael. 1989. The politics of government-NGO relations in Africa. World Development 17 (4): 569-587.

Byran, Anna. 2011. The Soviet poster collection. Wright Museum of Art Beloit College. Available at: https://pdfs.semanticscholar.org/bb6a/0164b227df2abc3fd c4406f b561e628216aa.pdf accessed April 5, 2020.

Cartier, Carolyn L. 2008 [2001]. Globalizing South China. Malden, MA: Blackwell. Available at: http://onlinelibrary.wiley.com.ezp.sub.su.se/book/10.1002/ 9780470712764 accessed February 4, 2016.

Cerwonka, Allaine, and Liisa H. Malkki, eds. 2007. Improvising theory: process and temporality in ethnographic fieldwork. Chicago: University of Chicago Press.

Chazan, Naomi. 1992. Africa's democratic challenge. World Policy Journal 9 (2): 279-307.

Clarke, Gerad. 1998. Non-governmental organizations (NGOs) and politics in the developing world. Political Studies 46 (1): 36-52.

Davies, T. 2014. NGOs: a new history of transnational civil society. New York: Oxford University Press.

De Certeau, Michel. 1984. The practice of everyday life. Berkeley: University of California Press.

Edwards, Michael, and David Hulme. 1996. "NGO performance and accountability: introduction and overview." In Beyond the magic bullet: NGO performance and accountability in the post-Cold War world, edited by Michael Edwards and David Hulme. West Hartford, CT: Kumarian Press, pp. 3-16.

Elias, Norbert, and John L. Scotson. 1994 [1965]. The established and the outsiders: a sociological inquiry into community problems. London: Sage.

Elyachar, Julia. 2011. The political economy of movements and gesture in Cairo. Journal of the Royal Anthropological Institute 17 (1): 82-99.

Faubion, James D., and George E. Marcus, eds. 2009. Fieldwork is not what it used to be: learning anthropology's method in a time of transition. Ithaca, NY: Cornell University Press.

Favret-Saada, Jeanne. 1990. About participation. Culture, Medicine and Psychiatry 14: 189-199.

Fisher, William F. 1997. Doing good? The politics and anti-politics of NGO practices. Annual Review of Anthropology 26: 439-464.

Flower, John, and Pamela Leonard. 1996. "Community values and state cooptation: civil society in the Sichuan countryside." In Civil society: challenging Western models, edited by Chris Hann and Elizabeth Dunn. London and New York: Routledge.

Fowler Alan. 1991. The role of NGOs in changing state-society relations: perspectives from Eastern and Southern Africa. Development Policy Review 9 (1): 53-84. 
Frankenberg, Ronald. 1957. Village on the border: a social study of religion, politics and football in a north Wales community. London: Cohen and West.

Frantz, Telmo Rudi. 1987. The role of NGOs in the strengthening of civil society. World Development 15 (supplement 1): 121-127.

Friedman, John. 1992. Empowerment: the politics of alternative development. Cambridge MA: Blackwell.

Garsten, Christina, and Anette Nyqvist. 2013a. "Entries: engaging organizational worlds." In Organizational anthropology: doing ethnography in and among complex organizations, edited by Christina Garsten and Anette Nyqvist. London: Pluto Press.

2013b. "Momentum: pushing ethnography ahead." In Organizational anthropology: doing ethnography in and among complex organizations, edited by Christina Garsten and Anette Nyqvist. London: Pluto Press.

Geertz, Clifford. 2000 [1973]. "Deep play: notes on the Balinese cockfight." In The interpretation of cultures. New York: Basic Books, pp. 412-453.

Grewal, Inderpal. 2005. Transnational America: feminism, diasporas, neoliberalism. Durham, NC: Duke University Press.

Gries, Peter Hays, and Stanley Rosen. 2004. "Introduction: popular protest and state legitimation in 21st century China." In State and society in 21st century China: crisis, contention, and legitimation, edited by Peter Hays Gries and Stanley Rosen. New York and London: Routledge.

Gupta, Akhil, and James Ferguson, eds. 1997a. "Discipline in practice: 'the field' as site, method, and location in anthropology." In Anthropological locations: boundaries and grounds of a field science, edited by Akhil Gupta and James Ferguson. Berkeley: University of California Press.

- eds. 1997b. Culture, power, place: explorations in critical anthropology. Durham, NC and London: Duke University Press.

Habermas, Jürgen. 1989. The structural transformation of the public sphere. Cambridge: Polity Press.

Hannerz, Ulf. 1967. Gossip, networks and culture in a black American ghetto. Ethnos 32 (1-4): 35-60.

Haviland, John Beard. 1977. Gossip, reputation, and knowledge in Zinacantan. Chicago: University of Chicago Press.

Huntington, Samuel P. 1991. The third wave: democratization in the late twentieth century. Norman: University of Oklahoma Press.

Kalir, Barak. 2006. The field of work and the work of the field: conceptualizing an anthropological research engagement. Social Anthropology 14 (2): 235-246.

Kamat, Sangeeta. 2004. The privatization of public interest: theorizing NGO discourse in a neoliberal era. Review of International Political Economy 11 (1): $155-176$.

Lewis, David, and Mark Schuller. 2017. Engagements with a productively unstable category: anthropologists and nongovernmental organizations. Current Anthropology 58 (5): 634-651.

Lin, George C. S. 1997. Red capitalism in South China. Vancouver: University of British Colombia Press.

Lind, Amy. 1992. "Power, gender and development: popular women's organizations and the politics of needs in Ecuador." In The making of social movements in Latin America: identity, strategy, and democracy, edited by Arturo Escobar and Sonia E. Alvarez. Boulder, CO: Westview.

Ma, Quisha. 2006. Non-governmental organizations in contemporary China: paving the way to civil society? London and New York: Routledge. 
Mahmud, Lilith. 2014. The brotherhood of Freemason sisters: gender, secrecy, and fraternity in Italian Masonic lodges. Chicago: University of Chicago Press.

Malinowski, Bronislaw. 1932 [1922]. Argonauts of the Western Pacific. London: G. Routledge \& Sons.

Marchand, Trevor H. J. 2015. "Managing pleasurable pursuits: utopic horizons and the arts of 'ignoring' and 'not knowing' among fine woodworkers." In Regimes of Ignorance: anthropological perspectives on the production and reproduction of non-knowledge, edited by Roy Dilley and Thomas G. Kirsch. New York: Berghahn Books.

Marcus, George E. 2009. "Introduction: notes toward an ethnographic memoir of supervising graduate research through anthropology's decades of transformation". In Fieldwork is not what it used to be: learning anthropology's method in a time of transition, edited by James D. Faubion and George E. Marcus. Ithaca, NY: Cornell University Press.

ed. 2000. Para-sites: a casebook against cynical reason. Chicago: University of Chicago Press.

1997. The uses of complicity in the changing mise-en-scène of anthropological fieldwork. Representations 59: 85-108.

1995. Ethnography in/of the world system: the emergence of multi-sited ethnography. Annual Review of Anthropology 24: 95-117.

Mehra, Rekha. 1997. Women, empowerment and economic development. Annals of the American Academy of Political and Social Sciences 554 (November 1997): 136-149.

Merry, Sally Engel. 1984. "Rethinking gossip and scandal." In Toward a general theory of social control, Vol. 1, edited by Donald Black. New York: Academic Press.

Narayan, Kirin. 1993. How native is a "native" anthropologist? American Anthropologist 95 (3): 671-686.

Naughton, Barry. 1995. Growing out of the plan: Chinese economic reform, 1978 1993. Cambridge: Cambridge University Press.

Noon, Mike, and Rick Delbridge. 1993. News from behind my hand: gossip in organizations. Organization Studies 14 (1): 23-36.

Ortner, Sherry B. 1995. Resistance and the problem of ethnographic refusal. Comparative Studies in Society and History 37 (1): 173-193.

Pan, Darcy. 2016. Laboring through uncertainty: an ethnography of the Chinese state, labor NGOs, and development. PhD dissertation, Stockholm University.

Rabinow, Paul, George E. Marcus, James D. Faubion, and Tobias Rees. 2008. Designs for an anthropology of the contemporary. Durham, NC and London: Duke University Press.

Rosnow, Ralph L. 1977. Gossip and marketplace psychology. Journal of Communication 27 (1): 158-163.

Samimian-Darash, Limor, and Paul Rabinow. 2015. "Introduction." In Modes of uncertainty: anthropological cases, edited by Limor Samimian-Darash and Paul Rabinow. Chicago: University of Chicago Press.

Schuller, Mark. 2009. Gluing globalization: NGOs as intermediaries in Haiti. PoLAR 32 (1): 84-104.

Schuller, Mark, and David Lewis. 2014. Anthropology of NGOs. Oxford Bibliographies. doi:10.1093/obo/9780199766567-0090 accessed March 16, 2016.

Scott, James. 1990. Domination and the arts of resistance: hidden transcripts. New Haven, CT: Yale University Press. 
Smith, Hazel. 2009. The erotics of gossip: fictocriticism, performativity, technology. Textual Practice 23 (6): 1001-1012.

Spires, Anthony. 2011. Contingent symbiosis and civil society in an authoritarian state: understanding the survival of China's grassroots NGOs. American Journal of Sociology 117 (1): 1-45.

2007. China's unofficial civil society: the development of grassroots NGOs in an authoritarian state. $\mathrm{PhD}$ dissertation, Yale University.

Srinivas, M. N. 1976. The remembered village. Berkeley: University of California Press.

Stoler, Ann Laura. 1992. "In Cold blood": hierarchies of credibility and the politics of colonial narratives. Representations 37: 151-189.

Tsing, Anna Lowenhaupt. 2005. Friction: an ethnography of global connection. Princeton, NJ: Princeton University Press.

Van Vleet, Krista. 2003. Partial theories: on gossip, envy and ethnography in the Andes. Ethnography 4 (4): 491-519.

Wakeman, Frederic. 1993. The civil society and public sphere debate: Western reflections on Chinese political culture. Modern China 19 (2): 108-138.

White, Luise. 2000. Speaking with vampires: rumor and history in colonial Africa. Berkeley: University of California Press.

World Bank. 1991. World development report 1991: the challenge of development. Washington, DC: World Bank/Oxford University Press.

Yang, Mayfair Mei-hui. 1994. Favors and banquets: the art of social relationships in China. Ithaca, NY: Cornell University Press.

Bach, Jonathan. 2010. "They come in peasants and leave citizens": urban villages and the making of Shenzhen, China. Cultural Anthropology 25 (3): 421-458.

Chan, Anita. 2001 China's workers under assault: the exploitation of labor in a globalizing economy. New York: M.E. Sharpe.

Chan, Chris King-chi. 2013. Community-based organizations for migrant workers' rights: the emergence of labor NGOs in China. Community Development Journal 48 (1): 6-22.

Dillon, Nara. 2011. "Governing civil society: adapting revolutionary methods to serve post-communist goals." In Mao's invisible hand: the political foundations of adaptive governance in China, edited by Sebastian Heilmann and Elizabeth J. Perry. Cambridge, MA: Harvard University Asia Center, pp. 138-164.

Fewsmith, Joseph. 2012. "Social management" as a way of coping with heightened social tension. China Leadership Monitor 36: 1-8.

Finder, Susan. 2014. How China classifies state secrets. The Diplomat, December 23. Available at: http://thediplomat.com/2014/12/how-china-classifies-state-secrets/ accessed March 9, 2015.

Fisher, William F. 1997. Doing good? The politics and anti-politics of NGO practices. Annual Review of Anthropology 26: 439-464.

Foucault, Michel. 2009. Security, territory, population: lectures at the collége de France 1977-1978. Translated by Graham Burchell. New York: Picador.

2008. The birth of biopolitics: lectures at the collége de France 1978-1979. Edited by Michel Senellart. New York: Palgrave-Macmillan.

Franceschini, Ivan. 2014. Labor NGOs in China: a real force for political change? The China Quarterly 218: 474-492.

Froissart, Chloé. 2005 The rise of social movements among migrant workers: uncertain strivings for autonomy. China Perspectives 61: 1-15.

Gallagher, Mary E. 2007 [2005]. Contagious capitalism: globalization and the politics of labor in China. Princeton, NJ and Oxford: Princeton University Press. 
2004. "China: the limits of civil society in a late Leninist state." In Civil society and political change in Asia: expanding and contracting democratic space, edited by Muthiah Alagappa. Stanford: Stanford University Press.

Gallagher, Mary E., and Baohua Dong. 2011. "Legislating harmony: labor law reform in contemporary China." In From iron rice bowl to informalization: markets, workers, and the state in a changing China, edited by Sarosh Kuruvilla, Ching Kwan Lee, and Mary E. Gallagher. Ithaca, NY and London: Cornell University Press.

Gries, Peter Hays, and Stanley Rosen. 2004. "Introduction: popular protest and state legitimation in 21st century China." In State and society in 21st century China: crisis, contention, and legitimation, edited by Peter Hays Gries and Stanley Rosen. New York and London: Routledge.

Howell, Jude. 2008. "Civil society and migrants," In Labor migration and social development in contemporary China, edited by Rachel Murphy. London: Routledge.

2003. "New directions in civil society: organizing around marginalized interests," in Governance in China, edited by Jude Howell. Oxford: Rowman \& Littlefield Publishers.

Human Rights in China (HRIC). 2007. State secrets: China's legal labyrinth. New York: HRIC. Available at: www.hrichina.org/sites/default/files/publication_pdfs/ hric_statesecrets-report.pdf accessed March 9, 2015.

Huang, Shumin. 1998. The spiral road: change in a Chinese village through the eyes of a communist party leader. Boulder, CO: Westview Press.

Lau, Mimi. 2018. Chinese campus crackdown on young Marxist activists expands in major cities. The South China Morning Post. Available at: www.scmp.com/ news/china/politics/article/2173090/chinese-campus-crackdown-young-marxistactivists-expands-major accessed August 23, 2019.

Lee, Ching Kwan, and Yonghong Zhang. 2013. The power of instability: unraveling the microfoundations of bargained authoritarianism in China. American Journal of Sociology 118 (6): 1475-1508.

Liang, Zhiping. 2011. "The death of a detainee: the predicament of status politics in contemporary China and the way out." In Governance of life in Chinese moral experience, edited by Everett Zhang, Arthur Kleinman, and Tu Weiming. London: Routledge.

Lin, George C. S. 1997. Red capitalism in South China. Vancouver: University of British Colombia Press.

Lubman, Stanley. 1999. Bird in a cage: legal reform in China after Mao. Stanford: Stanford University Press.

Ma, Quisha. 2006. Non-governmental organizations in contemporary China: paving the way to civil society? London and New York: Routledge.

Michael, Franz. 1988. "Law: a tool of power." In Human rights in the People's Republic of China, edited by Yuan-li Wu, Franz Michael, John F. Copper, Ta-Ling Le, Maria Hsia Chang, and A. James Gregor. Boulder, CO: Westview Press.

Oi, Jean C. 1995. The role of the local state in China's transitional economy. The China Quarterly 144: 1132-1149.

Pan, Darcy. 2019. "Thinking like a state: doing labor activism in South China." In Handbook of protest and resistance, edited by Teresa Wright. Cheltenham, UK: Edward Elgar Publishing, pp. 151-165.

2017. "Agents of change or status quo? Labor NGOs in South China." In Uncertain times: anthropological approaches to labor in a neoliberal world, edited by E. Paul Durrenberger. Boulder: University Press of Colorado, pp. 135-160.

Peerenboom, Randa1l. 2002. China's long march toward the rule of law. New York: 
Cambridge University Press.

Potter, Pitman. 1995. Foreign investment law in the People's Republic of China: dilemmas of state control. The China Quarterly 141: 155-185.

Power, Marcus. 2003. Rethinking development geographies. London: Routledge.

Pun, Ngai. 2009. "The making of a global dormitory labor regime: labor protection and labor organizing of migrant women in South China." In Labor migration and social development in contemporary China, edited by Rachel Murphy. London: Routledge.

2005. Made in China: women factory workers in a global workplace. Durham, $\mathrm{NC}$ and London: Duke University Press.

Pye, Lucian W. 1985. Asian power and politics: the cultural dimensions of authority. Cambridge, MA: Harvard University Press.

SACOM. 2005. Looking for Mickey Mouse's conscience: a survey on working conditions of Disney supplier factories in China. Available at: http://sacom.hk/wpcontent/uploads/2008/07/disney.pdf accessed September 15, 2015.

Schuller, Mark, and David Lewis. 2014. Anthropology of NGOs. Oxford Bibliographies. doi:10.1093/obo/9780199766567-0090 accessed March 16, 2016.

Scott, James C. 1998. Seeing like a state: how certain schemes to improve the human condition have failed. New Haven, CT: Yale University Press.

Siu, Helen F. 2007. Grounding displacement: uncivil urban spaces in postreform South China. American Ethnologist 34 (2): 329-350.

Solinger, Dorothy J. 1999. Contesting citizenship in urban China: peasant migrants, the state, and the logic of the market. Berkeley: University of California Press.

Spires, Anthony. 2007. China's unofficial civil society: the development of grassroots $N G O$ s in an authoritarian state. PhD dissertation, Yale University.

"The Chinese trade union holds its national congress." Made in China (2018, October 26). Available at: https://madeinchinajournal.com/2018/10/26/the-chinesetrade-union-holds-its-national-congress/ accessed August 23, 2019.

Turner, Karen G., James V. Feinerman, and R. Kent Guy. 2000. The limits of the rule of law in China. Seattle: University of Washington Press.

Unger, Jonathan. 1996. "Bridges": private business, the Chinese government and the rise of new associations. The China Quarterly 147: 795-819.

Wang, Ya Ping, Yanglin Wang, and Jiansheng Wu. 2009. Urbanization and informal development in China: urban villages in Shenzhen. International Journal of Urban and Regional Research 33 (4): 957-973.

Wang, Yuhua, and Carl Minzner. 2015. The rise of the Chinese security state. The China Quarterly 222: 339-359.

Wank, David. 1995. Private business, bureaucracy, and political alliance in a Chinese city. The Australian Journal of Chinese Affairs 33: 55-71.

Zhang, Li. 2001. Strangers in the city: reconfigurations of space, power, and social networks within China's floating population. Stanford: Stanford University Press.

Zhong, Lena Y. 2009. Communities, crime and social capital in contemporary China. Cullompton, UK: Willan Publishing.

Chen, Feng, and Xuehui Yang. 2017. Movement-oriented labor NGOs in South China: exit with voice and displaced unionism. China Information 32 (2): 155-175.

Cohen, Benjamin. 1998. The geography of money. Ithaca, NY: Cornell University Press.

Elyachar, Julia. 2010. Phatic labor, infrastructure, and the question of empowerment in Cairo. American Ethnologist 37 (3): 452-464.

Gallagher, Mary E. 2007 [2005]. Contagious capitalism: globalization and the politics 
of labor in China. Princeton, NJ and Oxford: Princeton University Press.

Gold, Thomas B. 1985. After comradeship: personal relations in China since the Cultural Revolution. The China Quarterly 104: 657-675.

Heilmann, Sebastian. 2011. "Policy-making through experimentation: the formation of a distinctive policy process." In Mao's invisible hand: the political foundations of adaptive governance in China, edited by Sebastian Heilmann and Elizabeth J. Perry. Cambridge, MA: Harvard University Asia Center, pp. 62-101.

Herzfeld, Michael. 2016. Cultural intimacy: social poetics and the real life of states, societies, and institutions. New York: Routledge.

Hildebrandt, Timothy. 2013. Social organizations and the authoritarian state in China. Cambridge: Cambridge University Press.

2011. The political economy of social organization registration in China. The China Quarterly 208: 970-989.

Humphrey, Caroline. 2003. "Stalin and the blue elephant: paranoia and complicity in post-communist metahistories." In Transparency and conspiracy: ethnographies of suspicion in the new world order, edited by Harry G. West and Todd Sanders. Durham, NC and London: Duke University Press.

Jacobs, Bruce J. 1979. A preliminary mode of particularistic ties in Chinese political alliances: kan-ch'ing and kuan-hsi in a rural Taiwanese township. The China Quarterly 78: 237-273.

Khalili, Laleh. 2007. Heroes and martyrs of Palestine: the politics of national commemoration. Cambridge: Cambridge University Press.

Kipnis, Andrew B. 1997. Producing guanxi: sentiment, self, and subculture in a North China village. Durham, NC and London: Duke University Press.

Labov, William, and Joshua Waletzky. 1966. "Narrative analysis: oral versions of personal experience." In Essays on the verbal and visual arts: proceedings of the 1966 annual spring meeting of the American Ethnological Society, edited by June Helm. Seattle, WA: American Ethnological Society.

Oi, Jean C. 1989. State and peasant in contemporary China: the political economy of village government. Berkeley: University of California Press.

Osburg, John. 2013. Anxious wealth: money and morality among China's new rich. Stanford: Stanford University Press.

Pan, Darcy. 2019. "Thinking like a state: doing labor activism in South China." In Handbook of protest and resistance, edited by Teresa Wright. Cheltenham, UK: Edward Elgar Publishing.

Polletta, Francesca. 2006. It was like a fever: storytelling in protest and politics. Chicago: University of Chicago Press.

Robin, Corey. 2004. Fear: the history of a political idea. Oxford: Oxford University Press.

Samimian-Darash, Limor, and Paul Rabinow. 2015. "Introduction.” In Modes of uncertainty: anthropological cases, edited by Limor Samimian-Darash and Paul Rabinow. Chicago: University of Chicago Press.

Scott, James C. 1990. Domination and the arts of resistance: hidden transcripts. New Haven, CT: Yale University Press.

Stern, Rachel E., and Jonathan Hassid. 2012. Amplifying silence: uncertainty and control parables in contemporary China. Comparative Political Studies 45 (10): $1230-1254$.

Stokes, Susan C. 1991. Hegemony, consciousness and political change in Peru. Politics \& Society 19 (3): 265-290.

Trouillot, Michel-Rolph. 2003. Global Transformations: anthropology and the mod- 
ern world. New York: Palgrave Macmillan.

Walder, Andrew G. 1986. Communist neo-traditionalism: work and authority in Chinese industry. Berkeley: University of California Press.

Yan, Yunxiang. 2009. The individualization of Chinese society. New York: Berg. 1996. The flow of gifts: reciprocity and social networks in a Chinese village. Stanford: Stanford University Press.

Yang, Mayfair Mei-hui. 2002. The resilience of guanxi and its new deployments: a critique of some new guanxi scholarship. The China Quarterly 170: 459-476.

1994. Favors and banquets: the art of social relationships in China. Ithaca, NY: Cornell University Press.

Zhang, Lu. 2019. "Worker protests and state response in present-day China: trends, characteristics, and new developments." In Handbook of protest and resistance, edited by Teresa Wright. Cheltenham, UK: Edward Elgar Publishing, pp. 119-136.

Abrams, Philip. 1988 [1977]. Notes on the difficulty of studying the state. Journal of Historical Sociology 1 (1): 58-89.

Appadurai, Arjun. 1996. Modernity at large: cultural dimensions of globalization. Minneapolis: University of Minnesota Press.

1991. Global ethnoscapes: notes and queries for a transnational anthropology. In Recapturing anthropology: working in the present, edited by Richard Fox. Santa Fe, NM: School of American Research Press, pp. 48-65.

Berlant, Lauren. 1998. Intimacy: a special issue. Critical Inquiry 24 (2): 281-288.

Bourdieu, Pierre. 2000. Pascalian meditations. Stanford, CA: Stanford University Press.

Brandtstädter, Susanne. 2016. The rebel as trickster and the ironies of resisting in contemporary China. In Irony, cynicism, and the Chinese state, edited by Hans Steinmüller and Susanne Brandtstädter. New York: Routledge.

De Certeau, Michel. 1984. The practice of everyday life. Berkeley: University of California Press.

Douglas, Mary. 1975. Implicit meanings: essays in anthropology. London: Routledge.

Edwards, Michael, and David Hulme. 1996. "NGO performance and accountability: introduction and overview." In Beyond the magic bullet: NGO performance and accountability in the post-Cold War world, edited by Michael Edwards and David Hulme. West Hartford, CT: Kumarian Press.

Elyachar, Julia. 2010. Phatic labor, infrastructure, and the question of empowerment in Cairo. American Ethnologist 37 (3): 452-464.

Fassin, Didier, and Richard Rechtman. 2009. The empire of trauma: an inquiry into the condition of victimhood. Translated by Rachel Gomme. Princeton, NJ: Princeton University.

Ferguson, James. W. 1994. The anti-politics machine: development, depoliticization, and bureaucratic power in Lesotho. Minneapolis: University of Minnesota Press.

Fernandez, Aloysius Prakash. 2004. NGOs and government in collaboration for development. MYRADA Rural Management Systems Series: Paper 39. Bangalore: Myrada.

Fernandez, W. James, and Mary Taylor Huber. 2001. "Introduction: the anthropology of irony." In Irony in action: anthropology, practice, and the moral imagination, edited by James W. Fernandez and Mary Taylor Huber. Chicago and London: University of Chicago Press.

Fisher, William F. 1997. Doing good? The politics and anti-politics of NGO practices. Annual Review of Anthropology 26: 439-464. 
Glaeser, Andreas. 2004. "Monolithic intentionality, belonging, and the production of state paranoia: a view through Stasi onto the late GDR." In Off stage on display: intimacy and ethnography in the age of public culture, edited by Andrew Skryock. Stanford: Stanford University Press.

2000. Divided in unity: identity, Germany and the Berlin Police. Chicago: University of Chicago Press.

Hassid, Jonathan. 2010. Pressing back: the struggle for control over China's journalists. PhD dissertation, University of California, Berkeley.

2008. Controlling the Chinese media: an uncertain business. Asian Survey 48 (3): 414-430.

Herzfeld, Michael. 2016. Cultural intimacy: social poetics and the real life of states, societies, and institutions. New York: Routledge.

1992. The social production of indifference: exploring the symbolic roots of Western bureaucracy. Chicago: University of Chicago Press.

Hirschman, Albert O. 1995. A propensity to self-subversion. Cambridge, MA: Harvard University Press.

James, Erica Caple. 2010. Democratic insecurities: violence, trauma, and intervention in Haiti. Berkeley and Los Angeles: University of California Press.

King, Gary, Jennifer Pan, and Margaret E. Roberts. 2013. How censorship in China allows government criticism but silences collective expression. American Political Science Review 107 (2): 326-343.

Lash, Scott, and Jonathan Urry. 1994. Economies of signs and space. London: Sage.

Lewis, David, and David Mosse, eds. 2006. Development brokers and translators: the ethnography of aid and agencies. Bloomfield, CT: Kumarian Press.

Mercer, Claire. 2002. NGOs, civil society and democratization: a critical review of the literature. Progress in Development Studies 2 (1): 5-22.

Merton, Robert. 1972. Insiders and outsiders: a chapter in the sociology of knowledge. American Journal of Sociology 78 (1): 9-47.

Midgal, Joel S. 2001. State in society: studying how states and societies transform and constitute one another. Cambridge: Cambridge University Press.

Pitkin, Hanna Fenichel. 1972. Wittgenstein and justice: on the significance of Ludwig Wittgenstein for social and political thought. Berkeley: University of California Press.

Polanyi, Michael. 1966. The tacit dimension. Chicago: University of Chicago Press. 1958. Personal knowledge: towards a post-critical philosophy. London: Routledge \& Kegan Paul.

Riles, Annelise. 2001. The network inside out. Ann Arbor: University of Michigan Press.

Schuller, Mark, and David Lewis. 2014. Anthropology of NGOs. Oxford Bibliographies. doi:10.1093/obo/9780199766567-0090 accessed March 16, 2016.

Scott, James C. 1998. Seeing like a state: how certain schemes to improve the human condition have failed. New Haven, CT: Yale University Press.

1990. Domination and the arts of resistance: hidden transcripts. New Haven, CT: Yale University Press.

Shryock, Andrew, ed. 2004. Off stage on display: intimacy and ethnography in the age of public culture. Stanford: Stanford University Press.

Spires, Anthony. 2007. China's unofficial civil society: the development of grassroots $N G O s$ in an authoritarian state. PhD dissertation, Yale University.

Steinmüller, Hans. 2016. "Introduction." In Irony, cynicism, and the Chinese state, edited by Hans Steinmüller and Susanne Brandtstädter. New York: Routledge. 
2013. Communities of complicity: everyday ethics in rural China. New York: Berghahn Books.

Stern, Rachel E., and Jonathan Hassid. 2012. Amplifying silence: uncertainty and control parables in contemporary China. Comparative Political Studies 45 (10): $1230-1254$.

Stevenson, Angus. 2010. ed. Oxford dictionary of English. Oxford: Oxford University Press.

Taussig, Michael. 1997. The magic of the state. New York: Routledge. 1992. The nervous system. New York: Routledge.

Tsai, Lily L. 2010. "Quantitative research and issues of political sensitivity in rural China." In Contemporary Chinese politics: new sources, methods, and field strategies, edited by Allen Carlson, Mary E. Gallagher, Kenneth Lieberthal, and Melanie Manion. New York: Cambridge University Press.

Yang, Guobin. 2009. The power of the Internet in China: citizen activism online. New York: Columbia University Press.

2008. "Contention in cyberspace." In Popular protest in China, edited by Kevin J. O’Brien. Cambridge, MA: Harvard University Press.

Appadurai, Arjun. 2006. The thing itself. Public Culture 18 (1): 15-21.

Ashforth, Adam. 1996. Of secrecy and the commonplace: witchcraft and power in Soweto. Social Research 63 (4): 1183-1234.

Barmé, Geremie R., and Sang Ye. 1997. "The Great Firewall of China.” Wired 5.06. June 1997. Available at: http://archive.wired.com/wired/archive/5.06/china.html accessed April 7, 2015.

Barth, Fredrik. 1990. The guru and the conjurer: transactions in knowledge and the shaping of culture in Southeast Asia and Melanesia. Man, New Series 25 (4): 640-653.

Benjamin, Walter. 1977. The origin of German tragic drama. Translated by John Osborne. London: New Left Books.

Boulding, Kenneth E. 1981. A preface to grants economics: the economy of love and fear. New York: Praeger.

Chase, Michael, and James Mulvenon. 2002. You've got dissent! Chinese dissident use of the Internet and Beijing's counter-strategies. Santa Monica, CA: RAND Corporation.

De Certeau, Michel. 1984. The practice of everyday life. Berkeley: University of California Press.

Deng, Iris. 2018. "Chinese internet users surge to 802 million in test of government's ability to manage world's biggest online community." The South China Morning Post. August 21. Available at: www.scmp.com/tech/china-tech/article/2160609/ chinese-internet-users-surge-802-million-test-governments-ability accessed on 20190919.

Derrida, Jacques. 1994. To do justice to Freud: the history of madness in the age of psychoanalysis. Critical Inquiry 20 (2): 227-266.

Ferme, Mariane C. 2001. The underneath of things: violence, history, and the everyday in Sierra Leone. Berkeley: University of California Press.

Gaenslen, Fritz. 1986. Culture and decision-making in China, Japan, Russia, and the United States. World Politics 39 (1): 78- 103.

George, Kenneth M. 1993. Dark trembling: ethnographic notes on secrecy and concealment in highland Sulawesi. Anthropological Quarterly 66 (4): 230-239.

Guo, Baogang, and Dennis V. Hickey. eds. 2010. Toward better governance in China: an unconventional pathway of political reform. Lanham, MD: Lexington Books. 
Gusterson, Hugh. 1998. Nuclear rites: a weapons laboratory at the end of the Cold War. Berkeley: University of California Press.

Harwit, Eric, and Duncan Clark. 2003. Shaping the Internet in China: evolution of political control over network infrastructure and content. Asian Survey 41 (3): 377-408.

Hegel, Georg Wilhelm Friedrich. 1977. Phenomenology of spirit. Translated by A. V. Miller. Oxford: Oxford University Press.

Herdt, Gilbert. 2003. Secrecy and cultural reality: utopian ideologies of the New Guinea men's house. Ann Arbor: University of Michigan Press.

1990. Secret societies and secret collectives. Oceania 60 (4): 360-381.

Herzfeld, Michael. 2015. Anthropology and the inchoate intimacies of power. American Ethnologist 42 (1): 18-32.

2009. The performance of secrecy: domesticity and privacy in public spaces. Semiotica 175: 135-162.

James, Erica Caple. 2010. Democratic insecurities: violence, trauma, and intervention in Haiti. Berkeley and Los Angeles: University of California Press.

Jensen, Casper Bruun, and Brit Ross Winthereik. 2013. Monitoring movements in development aid: recursive partnership and infrastructures. Cambridge, MA: MIT Press.

Jones, Graham M. 2014. Secrecy. Annual Review of Anthropology 43: 53-69.

2010. Modern magic and the war on miracles in French colonial culture. Comparative Studies in Society and History 52 (1): 66-99.

Jorgensen, Dan. 1990. Secrecy's turns. Canberra Anthropology 13 (1): 40-47.

Kalathil, Shanthi, and Taylor C. Boas. 2003. Open networks, closed regimes: the impact of the Internet on authoritarian rule. Washington, DC: Carnegie Endowment for International Peace.

Lazar, Sian. 2014. Historical narrative, mundane political time, and revolutionary moments: coexisting temporalities in the lived experience of social movement. Journal of the Royal Anthropological Institute 20 (S1): 91-108.

Lépinay, Vincent Antonin. 2011. Codes of finance: engineering derivatives in a global bank. Princeton, NJ: Princeton University Press.

Lewis, David, and David Mosse, eds. 2006. Development brokers and translators: the ethnography of aid and agencies. Bloomfield, CT: Kumarian Press.

Luhmann, Niklas. 1993. Risk: a sociological theory. New York: Aldine de Gruyter. 1979. Trust and power. Translated by Howard Davis, John Raffan, and Kathryn Rooney. Chichester: Wiley.

Lynch, Daniel C. 1999. After the propaganda state: media, politics, and "thought work" in reformed China. Stanford: Stanford University Press.

Mahmud, Lilith. 2014. The brotherhood of Freemason sisters: gender, secrecy, and fraternity in Italian Masonic lodges. Chicago: University of Chicago Press.

Masco, Joseph. 2006. The nuclear borderlands: the Manhattan Project in post-Cold War New Mexico. Princeton, NJ: Princeton University Press.

Mauss, Marcel. 2002 [1950]. The gift: the form and reason for exchange in archaic societies. Translated by W. D. Halls. London and New York: Routledge.

McCullough, Megan, B. 2014. The gender of the joke: intimacy and marginality in Murri humor. Ethnos 79 (5): 677-698.

Parsons, Talcott. 1978. Action theory and the human condition. New York: Free Press.

Patterson, Orlando. 1999. "Liberty against the democratic state: on the historical and contemporary sources of American distrust." In Democracy and trust, edited by Mark E. Warren. Cambridge: Cambridge University Press, pp. 151-207. 
Pei, Minxin. 2006. China's trapped transition: the limits of developmental autocracy. Cambridge, MA: Harvard University Press.

Scott, James C. 1998. Seeing like a state: how certain schemes to improve the human condition have failed. New Haven, CT: Yale University Press.

Simmel, Georg. 1906. The sociology of secrecy and of secret societies. American Journal of Sociology 11 (4): 441-498.

Stasch, Rupert. 2009. Society of others: kinship and mourning in a west Papuan place. Berkeley: University of California Press.

Strathern, Marilyn, ed. 2000. Audit cultures: anthropological studies in accountability, ethics, and the academy. London: Routledge.

Taussig, Michael. 1999. Defacement: public secrecy and the labor of the negative. Stanford: Stanford University Press.

Teiwes, Frederick C., and Warren Sun. 2007. The end of the Maoist era: Chinese politics during the twilight of the Cultural Revolution, 1972-1976. Armonk: M. E. Sharpe.

Thornton, Patricia M. 2010. "Censorship and surveillance in Chinese cyberspace: beyond the Great Firewall." In Chinese politics: state, society, and the market, edited by Peter Hays Gries and Stanley Rosen. London: Routledge.

Van de Port, Mattijs. 2006. Visualizing the sacred: video technology, "televisual" style, and the religious imagination in Bahian Candomblé. American Ethnologist 33 (3): 444-461.

West, Harry G., and Todd Sanders, eds. 2003. Transparency and conspiracy: ethnographies of suspicion in the new world order. Durham and London: Duke University Press.

White, Luise. 2000. Speaking with vampires: rumor and history in colonial Africa. Berkeley: University of California Press.

Yang, Guobin. 2009. The power of the Internet in China: citizen activism online. New York: Columbia University Press.

2003. The co-evolution of the Internet and civil society in China. Asian Survey 43 (3): 405-422.

Zhang, Enyu. 2009. "Contextualizing the practice of regionalization in China's foreign policy." In China and the global politics of regionalization, edited by Emilian Kavalski. Farnham: Ashgate Publishing.

Arellano-Lopéz, Sonia, and James F. Petras. 1994. Nongovernmental organizations and poverty alleviation in Bolivia. Development and Change 25: 555-568.

Beeman, William O. 1999. Humor. Journal of Linguistic Anthropology 9 (1-2): 103-106.

Chan, Anita. 1998. "Labor relations in foreign-funded ventures, Chinese trade unions, and the prospects for collective bargaining." In Adjusting to capitalism: Chinese workers and the state, edited by Greg O'Leary. New York: M. E. Sharpe, pp. 122-149.

Chan, Chris King-chi, and Elaine Sio-leng Hui. 2014. The development of collective bargaining in China: from "collective bargaining by riot" to "Party state-led wage bargaining." The China Quarterly 217: 221-242.

Clarke, Gerard. 1998a. The politics of NGOs in Southeast Asia: participation and protest in the Philippines. London: Routledge.

1998b. Nongovernmental organizations (NGOs) and politics in the developing world. Political Studies 46 (1): 36-52.

Farrington, John, and David J. Lewis, eds. 1993. Nongovernmental organizations and the state in Asia: rethinking roles in sustainable agricultural development. London: 
Routledge.

Feldman, Shelley. 1997. NGOs and civil society: (un)stated contradictions. The Annals of the American Academy of Political and Social Science 554: 46-65.

Franceschini, Ivan. 2014. Labor NGOs in China: a real force for political change? The China Quarterly 218: 474-492.

Froissart, Chloé. 2005 The rise of social movements among migrant workers: uncertain strivings for autonomy. China Perspectives 61: 1-15.

Goldstein, Donna M. 2003. Laughter out of place: race, class, violence, and sexuality in a Rio shantytown. Berkeley: University of California Press.

Hobsbawm, Eric. 1968. Laboring men: studies in the history of labor. London: Weidenfeld and Nicolson.

Hojman, David E. 1993. Nongovernmental organizations (NGOs) and the Chilean transition to democracy. European Review of Latin American and Caribbean Studies 54: 7-24.

Lee, Ching Kwan, and Yuan Shen. 2011. "The anti-solidarity machine? Labor nongovernmental organizations in China." In From iron rice bowl to informalization: markets, workers, and the state in a changing China, edited by Sarosh Kuruvilla, Ching Kwan Lee, and Mary E. Gallagher. Ithaca, NY and London: Cornell University Press.

Lee, Ching Kwan, and Yonghong Zhang. 2013. The power of instability: unraveling the microfoundations of bargained authoritarianism in China. American Journal of Sociology 118 (6): 1475-1508.

McCullough, Megan B. 2014. The gender of the joke: intimacy and marginality in Murri humor. Ethnos 79 (5): 677-698.

Mercer, Claire. 2002. NGOs, civil society and democratization: a critical review of the literature. Progress in Development Studies 2 (1): 5-22.

Pan, Darcy. 2017. "Agents of change or status quo? Labor NGOs in South China." In Uncertain times: anthropological approaches to labor in a neoliberal world, edited by E. Paul Durrenberger. Boulder: University Press of Colorado, pp. 135-160.

Scott, James C. 1990. Domination and the arts of resistance: hidden transcripts. New Haven, CT: Yale University Press.

Seizer, Susan. 2005. Stigmas of the Tamil stage: an ethnography of special drama artists in South India. Durham, NC: Duke University Press.

Smith, Andrea. 2007. "Introduction: the revolution will not be funded." In The revolution will not be funded: beyond the non-profit industrial complex, edited by INCITE! Women of Color against Violence. Cambridge, MA: South End Press.

Stern, Rachel E., and Kevin J. O'Brien. 2012. Politics at the boundary: mixed signals and the Chinese state. Modern China 38 (2): 174-198. 